
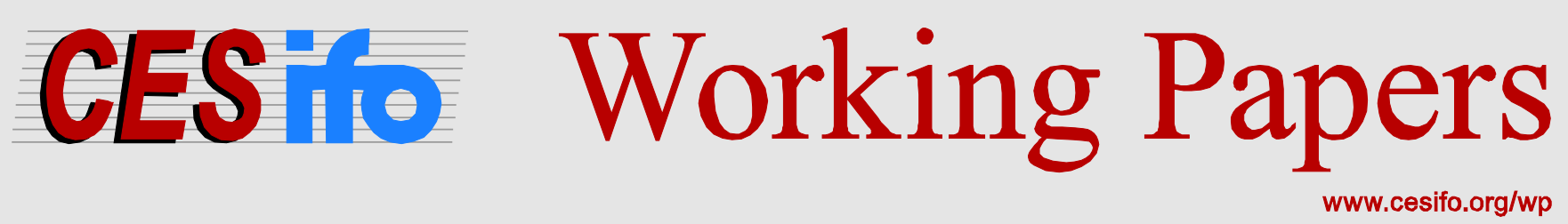

\title{
Political Accountability and Real Authority of Government Bureaucracy
}

\author{
Marina Dodlova
}

CESIFO WORKING PAPER NO. 4443

CATEgory 2: Public CHOICE

ORIGINAL VERSION: OCTOBER 2013

THIS VERSION: DECEMBER 2013

An electronic version of the paper may be downloaded

- from the SSRN website:

- from the RePEc website:

- from the CESifo website:

www.SSRN.com

www.RePEc.org

www.CESifo-group.org/wp

\section{CESifo}




\title{
Political Accountability and Real Authority of Government Bureaucracy
}

\begin{abstract}
In a country with weak institutional constraints on the executive, the real power might belong to the government bureaucracy rather than to an autocratic leader. We combine the AghionTirole definition of formal and real authority with the Barro-Ferejohn model of political agency to study the relationship between the accountability of elected politicians and the extent to which their subordinate bureaucrats have real decision-making power. We show that the lower is the level of political accountability, the lower should be real authority at the bottom of the government hierarchy. Empirically, we find that in countries with lower political accountability those in political power have less authority over the public administration. On the contrary, countries with higher political accountability have bigger governments in terms of administration employment.
\end{abstract}

JEL-Code: D720, D730, D830, H110.

Keywords: political accountability, bureaucracy, real authority, decision-making, government employment.

Marina Dodlova

German Institute of Global and Area Studies (GIGA)

Institute of Latin American Studies

Neuer Jungfernstieg 21

Germany - 20354 Hamburg

mdodlova@gmail.com

I thank Giorgio Bellettini, Pierre Boyer, Eric Brousseau, Bertrand Crettez, Scott Gehlbach, Sergei Guriev, Andrew Schrank, Konstantin Sonin, Anton Suvorov, Michael Ting, and Stefan Voigt for valuable comments and discussions on earlier versions of this paper. I'm also grateful to the RES 2013 participants and audience at the CAE 2013, ESWC 2010, CESifo PSE 2009, ISNIE 2008 and EEA 2008 meetings as well as seminar audience at UQAM, University Paris Ouest, GIGA and Bank of Canada for critics and helpful advice. 


\section{Introduction}

In any political regime, the real authority over policy decisions resides in the hands of the political elite. Even in mature democracies, relatively few decisions are made directly by the public and most of policies are implemented by appointed bureaucrats. Aghion and Tirole (1997) note that "the president of a country really controls only a small number of the decisions made by the executive branch," and, similarly, "shareholders have limited control over their board of directors, which itself may be subject to the domination of the top executives, who in turn often rubber-stamp the divisions' projects, and so forth." If formal authority generally resides at the top of any organizational hierarchy (Baker, Gibbons and Murphy, 1999), real authority does not necessarily pertain to the top. Yet, the structure of bureaucracy itself depends on the political regime (Tullock, 1965, 1980; Buchanan, 1986).

In this paper, we construct a simple model of government organization in different political regimes, and use cross-country and within-country data to validate our theoretical findings. A self-interested politician may be more interested in rent seeking than in policy efficiency, thus distorting the bureaucrats' incentives. When the politician is more concerned with seeking rents, rather than controlling her bureaucrats, the latter have greater discretion over policy and thus more opportunities to enrich themselves. Furthermore, the bureaucrats have strong incentives to increase this discretion (have more real power), because this further enhances their own opportunities to extract rents. If the politician cares more about the policy outcomes (e.g., because she expects to stand up for the election in the future), she exercises more control over her bureaucrats. In this case, the bureaucrats seek to increase their formal authority and expands their formal overload by policy projects. Hence, the level of rents extracted at the top strongly affects the scope of rents at the bottom as well as the nature of agency problems within the government bureaucracy.

Our modeling approach inherits the main building blocks of the Barro-Ferejohn political accountability model (Barro, 1973; Ferejohn, 1986) and the Aghion-Tirole authority model (Aghion and Tirole, 1997). We extend the Aghion-Tirole's analysis by considering the three-level hierarchy of both the strictly vertical and flat structure. Within the flat hierarchy, a higher-level bureaucrat hires several agents, so that each of them is charged with its own range of projects. The politician is elected to conduct policies, which provide a certain level of public welfare for citizens. The politicians is disciplined by her future election prospects in a retrospective voting model. The two-tier bureaucracy helps the politician make policy decisions by acquiring information about different policy outcomes (e.g., Tirole, 1986; Guriev, 2004; Egorov, Guriev, and Sonin, 2009). The decision rights mainly are not contractible; elected officials may rubber-stamp their appointed bureaucratic subordinates' decisions and proposals without effective control. 
The theoretical analysis reveals two important features of the government bureaucracy. First, under lower accountability, the bureaucrats are more likely to participate in policy decisions compared to higher political accountability regimes. Second, in higher accountability regimes government bureaucracies are bigger than in lower accountability regimes in terms of government administration employment. The cross-country data on institutional development from the World Bank and the MINEIE ${ }^{1}$ allow us to corroborate these predictions. The within-country variation of the level of government administration employment in American states also supports the second finding. It appears that in low accountability regimes the bureaucratic machinery is indeed likely to be smaller and less controlled by the politicians.

Our paper inherits the tradition of Downs (1967), Tullock (1965) and Buchanan (1986) that the excessive growth of a bureaucracy is a appropriate feature of organizational problems within government. Furthermore, our approach is consistent with the idea of poor state capacity of Acemoglu et al. (2011), however, proposes that the bureaucracy may enlarge because of not only patronage but also rent seeking behavior of bureaucrats. I highlight the economic mechanism of accumulating rents within government on the basis of real decision making power.

Our second result (greater bureaucratization in high-accountability regimes) is consistent with earlier empirical evidence. Persson and Tabellini (1999) examine government spending under presidential and parliamentary regimes and Lassen (2000) considers the link between political accountability and the size of government measured by the level of tax revenue. They show that "as presidential regimes empirically are associated with less political accountability voters have less control on politicians, leading to smaller governments" (Lassen 2000, p. 5). Enikolopov (2010) demonstrates that the level of public employment is likely to be higher in those local governments that are headed by elected chief executives rather than appointed chief executives because the former are more likely engaged in vote buying activities, one form of which is the excessive level of public employment. We suggest that the lower is political accountability, the more influence appointed officials have and the smaller is the size of the government bureaucracy. Hence, we confirm his result in the sense that the level of government employment is lower in countries with powerful bureaucracies where appointed officials play a larger role in decision-making. Brown, Earle, and Gehlbach (2007) find that post-Soviet privatization has had a more positive effect on firm performance in regions with relatively large state bureaucracies. Schiavo-Campo, de Tomasso, and Mukherjee (1997) demonstrate that employment in government administration is greater in richer countries with higher gross domestic product per capita, which is a good proxy for the level of political accountability (See also Brym and Gimpelson, 2004).

\footnotetext{
${ }^{1}$ The "Institutional profiles" database is assembled by the French Ministry for the Economy, Industry and Employment (MINEIE) and can be found at http://www.cepii.fr/
} 
The conflict of interests between politicians and bureaucrats also is a classic topic in political economy. To be informed about costs and benefits from different alternative policies, politicians rely on bureaucrats as experts, which causes at least two effects. On the one hand, policymakers aim to buy the loyalty of bureaucrats by doing favors for them (e.g., see Gregory and Lazarev, 2003, on top-end cars provided by the Stalin regime to its loyalists). On the other hand, rulers prefer loyal rather than capable viziers (Egorov and Sonin, 2011). The literature extensively discusses the information asymmetry and delegation problem within government. Boadway and Sato (2006) consider a model of bureaucratic advice to compare the efficacy of centralized versus decentralized modes of governance and argue that politicians may find it useful to decentralize the bureaucracy so that different dimensions of the project or policy are examined by different bureaucrats. Li and Suen (2004) focus on the benefit of delegating decision-making on a given project to an expert in nonmarket organizations. They consider delegation as a result of similar preferences of decision-makers and experts. Alesina and Tabellini $(2007,2008)$ argue that the allocation of tasks between politicians and bureaucrats depends on their different motivation (reelection versus career concerns) originating from different accountability mechanisms. Acemoglu and Verdier (2000) show that "when monitoring of bureaucrats becomes more difficult, they should receive higher wages, and government intervention should become relatively rare. However, if government intervention continues to be required despite the increased difficulty of monitoring, the number of bureaucrats and their wages should increase, very much as if the bureaucracy were expanding to seek additional rents." They come to the conclusion that the optimal size of government in a case when bureaucrats can be corruptible is greater than in a case when corruption is not possible in the economy. Acemoglu et al. (2011) state that the bureaucracy becomes excessively large because of the rich-bureaucrats coalition's actions to generate enough political support.

Bureaucratic power in the political decision-making process has been broadly discussed in the literature, especially in a variety of case studies. Johnson (1982) describes the case of Japan and mentions the important role of bureaucrats in policymaking, whereas Pempel (1984) argues that Japan has developed an effective balance between the extremes of total bureaucratic control and total political control. In the case of the United States, Hugh Heclo (1984) argues that the balance has not yet been found ${ }^{2}$. In France it has also been recognized that top-level bureaucrats affect considerably policy decisions. Suleiman (1974) describes the relationship between the French higher civil servants and the French politicians as a complex and ritually structured dance.

\footnotetext{
${ }^{2}$ These essays are a part of a book edited by Ezra Suleiman (1984) containing several essays which study the degree of influence that civil servants exert on the political process in the United States, Italy, Japan, France, Britain, Germany, Norway, and Chile.
} 
The rest of the paper is organized as follows. Section 2 presents the model. Section 3 contains the results of the cross-country and within-country studies and produces empirical evidence for different accountability - bureaucratization political regimes. Section 4 concludes.

\section{Theory}

This section presents a simple model of the two-tier government hierarchy. We consider a politician who chooses the level of efforts to control bureaucracy. In effect, this is the choice between two types of bureaucracy organizational structures. The level of Politician's accountability is proxied by the voters' reservation utility she needs to provide to be re-elected (see Barro, 1973, and Ferejohn, 1986).

\subsection{Set up}

There is a Politician (she) who holds an elective office, a Minister (he), a high-level bureaucrat, and an Agent (it), a low-level bureaucrat. The success of the policy projects and their respective payoffs depend on the level of efforts the three players choose.

Each policy is a pair of projects $(N, n)$, where high-level project $N \in\left\{N^{P}, N^{M}, \bar{N}\right\}$ is jointly determined by Politician and Minister, while low-level project $n \in\left\{n^{M}, n^{A}, \bar{n}\right\}$ is jointly determined by Minister and Agent. Politician and Minister have formal authority over projects $N$ and $n$, respectively: they have a right to approve a specific project. Minister and Agent have real authority over these projects $N$ and $n$, respectively: they may propose a specific project to their principals. $N^{P}$ is the project most preferred by Politician, $N^{M}$ is the (high-level) project most preferred by Minister, $\bar{N}$ is the other project, which is dominated for both Politician and Minister. $n^{A}$ is the low-level project most preferred by Agent, $n^{M}$ is the low-level project most preferred by Minister, $\bar{n}$ is the other project, which is dominated for both Agent and Minister. $\bar{N}$ and $\bar{n}$ yield a sufficiently large negative payoff for all actors, so that inaction is not preferred.

All three actors exert efforts to learn the pay-offs of all projects. The Politician and Agent's efforts are one-dimensional, while the Minister's effort is two-dimensional as he works both with Politician and Agent.

The three agents make the choice of their efforts simultaneously ${ }^{3}$. When the Politician's effort is $E_{P} \in[0,1]$, the Minister's effort is $\left(E_{M}, e_{M}\right) \in[0,1] \times[0,1]$, and the Agent's effort is

\footnotetext{
${ }^{3}$ The sequential model of acquiring information essentially yields a similar result. "Sequential investigations usually are less time-consuming for the principal, who can already build on an existing report. On the other hand, the principal may not want to wait until the report accrues to start her investigation, since otherwise she may be forced to accept the agent's proposal by lack of time" (Aghion and Tirole, 1997, p. 7).
} 
$e_{A} \in[0,1]$, then the expected pay-offs are as follows:

$$
\begin{gathered}
E\left[V^{P}\right]=\rho+\pi R+E_{P} u^{P}\left(N^{P}\right)+\left(1-E_{P}\right) E_{M} u^{P}\left(N^{M}\right)-c_{P}\left(E_{P}\right) \\
\begin{aligned}
& E\left[V^{M}\right]= E_{P} u^{M}\left(N^{P}\right)+\left(1-E_{P}\right) E_{M} u^{M}\left(N^{M}\right)+e_{M} u^{M}\left(n^{M}\right) \\
&+\left(1-e_{M}\right) e_{A} u^{M}\left(n^{A}\right)-c_{M}\left(E_{M}\right)-c_{M}\left(e_{M}\right), \\
& E\left[V^{A}\right]=e_{M} u^{A}\left(n^{M}\right)+\left(1-e_{M}\right) e_{A} u^{A}\left(n^{A}\right)-c_{A}\left(e_{A}\right) .
\end{aligned}
\end{gathered}
$$

where $\rho$ denotes extracted rent, $\pi$ is reelection probability, and $R$ is value from holding office.

Formulas (1)-(3) are based on a standard approach of modeling real versus formal authority first suggested by Aghion and Tirole (1997) but extended to a three-level hierarchy. Any government agent exerting effort $\varepsilon$, where $\varepsilon=E_{P}, E_{M}, e_{M}, e_{A}$, perfectly learns the payoffs of all screened projects with probability $\varepsilon$. With probability $1-\varepsilon$ he (she/it) learns nothing and still looks at the projects as being identical. Further, we assume that information is soft, i.e., it cannot be verified by the other party. The communication is thus interpreted as a pure suggestion to choose a specific project. We also assume that $u^{P}(\bar{N})=u^{M}(\bar{N})=u^{M}(\bar{n})=u^{A}(\bar{n})<<0$ so that inaction is not preferable for an uninformed agent. If no project is implemented, the benefits of three agents come to zero.

For simplicity suppose that each project type is associated with a verifiable monetary gain or profit for every agent so that utility of realized projects are constants. If the project preferred by the principal of any level is implemented, then it yields $B_{N}$ or $B_{n}$ for the controlling party and $\beta_{N} b_{N}$ or $\beta_{n} b_{n}$ for the other party. Otherwise, if the project preferred by the agent at any level is approved, then it produces $\alpha_{N} B_{N}$ or $\alpha_{n} B_{n}$ for the controlling party and $b_{N}$ or $b_{n}$ for the other party. We assume that all $B_{N}, B_{n}, b_{N}, b_{n}$ are positive scalars. To summarize, the high-level projects, $N^{P}$ and $N^{M}$, and the low-level projects $n^{M}$ and $n^{A}$, if approved, yield the following gains for three agents:

\begin{tabular}{|c|c|c|c|}
\hline & Politician & Minister & Agent \\
\hline$N^{P}$ & $B_{N}$ & $\beta_{N} b_{N}$ & 0 \\
$N^{M}$ & $\alpha_{N} B_{N}$ & $b_{N}$ & 0 \\
$n^{M}$ & 0 & $B_{n}$ & $\beta_{n} b_{n}$ \\
$n^{A}$ & 0 & $\alpha_{n} B_{n}$ & $b_{n}$ \\
\hline
\end{tabular}

Table 1: Payoff Structure

This implies that $\alpha_{j}, \beta_{j} \in(0,1], j=N, n$ are congruence parameters. Thus, we assume that the preferred projects yield positive payoffs not only for the informed party but also for the other party. All these gains are common knowledge. 
Each of three players has a constraint. The Politician's constraint is the state budget, $\tau y=\rho+c_{P}\left(E_{P}\right)$, where $y$ is the economy's product (per capita), $\tau$ is the tax rate, $\rho$ is the amount of rent Politician appreciates, and $c_{P}(\cdot)$ is the Politician's cost function for exerting efforts on policy making. The Minister's cost function is $c_{M}(\cdot)$ and his efforts should satisfy the physical capability constraint $E_{M}+e_{M} \leq 1$. Indeed, Minister is an intermediate employee in the hierarchical structure and so has to allocate his time between the upper and lower tiers' charges. The Agent's cost function is $c_{A}(\cdot)$. For the sake of simplicity, we assume that $c_{P}(\cdot)=$ $\lambda c_{M}(\cdot)=\lambda^{2} c_{A}(\cdot)=\lambda^{2} c(\cdot)$, where $c(\cdot)$ is twice differentiable, increasing, and strictly concave; $c(0)=0, c^{\prime}(0)=0, c^{\prime}(1)=+\infty$.

Politician is risk-neutral in government projects. Bureaucrats are protected by limited liability, and they receive not only the benefits from projects $N$ and $n$, but also the wages $w_{M}$ and $w_{A}$, respectively. In a core model we do not focus on the impact of government wages and assume without loss of generality that Minister and Agent are infinitely averse to income risk in projects $N$ and $n$, respectively, so that they receive a constant wage equal to their reservation wage of zero ${ }^{4}$.

There is a continuum of identical voters of mass 1 , where each produces the same income $y$. They finance the government through proportional income taxes of rate $\tau$. Thus, the voters receive the income available after taxes and some benefits from the state's activity, $H\left(\xi E_{P}, \zeta e_{M}\right)$, that is public good. We assume that the interests of the controlling parties are congruent in some way with those of the citizens. It is known that any effort by the controlling party leads to some positive policy outcomes for citizens, although it is not the maximum efficient policy choice $(0<\xi \ll 1$ and $0<\zeta \ll 1)$.

The voters coordinate on the same retrospective voting strategy $\bar{w}$, punishing the incumbent for bad behavior and rewarding her for good behavior by reelection ${ }^{5}$.

Politician is re-elected $(\pi=1)$ if the utility of each of her subjects, $w=(1-\tau) y+$ $H\left(\xi E_{P}, \zeta e_{M}\right)$, exceeds the reservation level $\bar{w} \geq 0$. (Otherwise, $\pi=0$.) We require the full homogeneity of voters, and $\bar{w}$ can be interpreted as a certain "focal" threshold that is the most expected from the incumbent. Low $\bar{w}$ corresponds to low accountability, because in this case the Politician could extract a lot of rent, while high $\bar{w}$ reflects high accountability.

We focus on the subgame perfect Nash equilibrium: voters announce $\bar{w}$ to maximize their utility, anticipating that the incumbent will then choose $\rho$ to maximize her expected utility, given the constraint that she will be re-elected if and only if she provides voters with a utility of no less than the welfare reservation level $\bar{w}$.

The timing of this two-period game is as follows:

\footnotetext{
${ }^{4}$ We consider the impact of positive government wages on bureaucratic incentives below in a separate section.

${ }^{5}$ The political accountability model is based on Persson and Tabellini (2000), Chapter 4.
} 
1. Voters announce their reservation utility $\bar{w}$ for reelecting the incumbent.

2. Politician selects $\tau$, the tax rate, and $\rho$, the amount of rent she appropriates.

3. Politician, Minister, and Agent simultaneously decide how much efforts to exert.

4. Politician, Minister, and Agent communicate with each other about the projects' payoffs (if informed), and the controlling parties of any level project, $N$ or $n$, finally approves the projects.

5. Pay-offs are realized. Politician is either re-elected (and gets $R^{6}$.), or removed from power in the second period.

\subsection{Real authority under high and low accountability}

We consider first a hierarchy as depicted in Figure 1 and examine the allocation of real authority. Politician has formal authority over project $N$ so she can overrule Minister's propositions on project $N$, whereas Minister can override Agents' propositions on project $n$. Thus, the principal at every level overrides her agent's suggestion if she is informed and the agent's recommendation is not perfectly "congruent." In this case, the principal has both formal and real authority over the choice of project. Otherwise, the principal rubber-stamps the agent's proposal, and then the agent at every level applies his/its real authority.

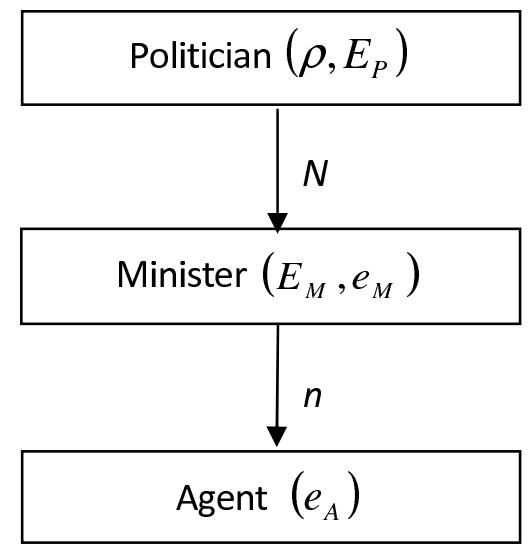

Figure 1: Vertical Hierarchy

The citizens vote for the only politician who appoints the bureaucrats for screening government projects. Politician's expected utility is composed of rent $(\rho)$, value from holding office in

\footnotetext{
${ }^{6} R$ is taken as the exogenous future payoff from holding office. By following the strategy of Persson, Roland and Tabellini (1997) we relax this proposition in Appendix by endogenizing $R$ as the expected present value of rents $\rho$ and benefits from $N$ projects in future periods.
} 
the next period $(R)$, and benefits from implementing high-level project $N$ :

$$
E\left[V^{P}\right]=\rho+\pi R+E_{P} B_{N}+\left(1-E_{P}\right) E_{M} \alpha_{N} B_{N} .
$$

The politician's efforts are financed through proportional income taxes $\tau$. The government's budget constraint takes the following form ${ }^{7}$ :

$$
\tau y=c_{P}\left(E_{P}\right)+\rho .
$$

The probability of reelection is based on the retrospective strategy, so it equals one if the citizens' utility will be no less than the reservation level $\bar{w}$ :

$$
\pi= \begin{cases}1, & \text { if } W\left(c_{P}\left(E_{P}\right), \rho\right) \geq \bar{w} \\ 0, & \text { otherwise }\end{cases}
$$

As mentioned before, we define identical citizens' preferences as the sum of income available after taxes plus benefits from the adopted policy projects. Then, using budget constraint (2), the citizens' observed welfare can be written as:

$$
\begin{array}{r}
W\left(c_{P}\left(E_{P}\right), \rho\right)=(1-\tau) y+H\left(\xi E_{P}, \zeta e_{M}\right)= \\
y-c_{P}\left(E_{P}\right)-\rho+H\left(\xi E_{P}, \zeta e_{M}\right) .
\end{array}
$$

The voting strategy of the constituency creates a trade-off for Politician between rents and benefits from reelection.

We solve the game from end to beginning. First, we find the strategies of Politician, Minister and Agent given a reservation utility. Second, we define the equilibrium level of reservation utility, announced by voters.

Let the voters announce a certain level of reservation utility. Politician has two alternatives. One is to please the voters to win reelection. Then, she extracts a maximum possible level of rent that allows her to be reelected. We call this case by the high accountability regime. Taking into account (2) and (3), the optimal level of rents extracted by Politician if she cares about reelection will be:

$$
\bar{\rho}^{h}=y-c_{P}\left(E_{P}\right)-\bar{w}+H\left(\xi E_{P}, \zeta e_{M}\right) .
$$

The strategies of bureaucrats need more detailed consideration. The expected utilities of Minister and Agent can be written as:

$$
\begin{array}{r}
E\left[V^{M}\right]=E_{P} \beta_{N} b_{N}+\left(1-E_{P}\right) E_{M} b_{N}+e_{M} B_{n} \\
+\left(1-e_{M}\right) e_{A} \alpha_{n} B_{n}-c_{M}\left(E_{M}\right)-c_{M}\left(e_{M}\right),
\end{array}
$$

\footnotetext{
${ }^{7}$ The full government's budget constraint is equal to $\tau y=c_{P}\left(E_{P}\right)+\rho+w_{M}+w_{A}$ but we assume that the bureaucrats are infinitely income averse and their wages come to zero.
} 


$$
E\left[V^{A}\right]=e_{M} \beta_{n} b_{n}+\left(1-e_{M}\right) e_{A} b_{n}-c_{A}\left(e_{A}\right)
$$

s.t. $E_{M}+e_{M} \leq 1$, the Minister's physical constraint. Minister is limited in his physical capabilities to acquire information in both directions, and in the equilibrium we count this inequality as binding $E_{M}+e_{M}=1$. The second term in equation (4) $\left(1-E_{P}\right) E_{M} b_{N}$ describes real authority that Minister applies for the choice of upper-level project $N$ whereas the fourth component $\left(1-e_{M}\right) e_{A} \alpha_{n} B_{n}$ indicates his action of rubber-stamping the Agent's proposal.

The reaction curves of Politician, Minister and Agent under high accountability will be the following:

$$
\begin{gathered}
c_{P}^{\prime}\left(E_{P}\right)=\left(1-\alpha_{N} E_{M}\right) B_{N}+H^{\prime}\left(E_{P}\right), \\
c_{M}^{\prime}\left(E_{M}\right)-c_{M}^{\prime}\left(e_{M}\right)=\left(1-E_{P}\right) b_{N}-B_{n}\left(1-\alpha_{n} e_{A}\right), \\
c_{A}^{\prime}\left(e_{A}\right)=\left(1-e_{M}\right) b_{n} .
\end{gathered}
$$

The second alternative of Politician is not to please voters. The best policy, then, is to forget about reelection and extracts the maximum rent left after her benefits from government projects:

$$
\bar{\rho}^{l}=y-c_{P}\left(E_{P}\right)
$$

We call this case by low accountability because it's equivalent to the case as if the voters announce the zero reservation welfare. In the low accountability regime the strategies of Politician, Minister and Agent are described by the following reaction curves:

$$
\begin{gathered}
c_{P}^{\prime}\left(E_{P}\right)=\left(1-\alpha_{N} E_{M}\right) B_{N} \\
c_{M}^{\prime}\left(E_{M}\right)-c_{M}^{\prime}\left(e_{M}\right)=\left(1-E_{P}\right) b_{N}-B_{n}\left(1-\alpha_{n} e_{A}\right), \\
c_{A}^{\prime}\left(e_{A}\right)=\left(1-e_{M}\right) b_{n} .
\end{gathered}
$$

Systems of equations (5) and (7) show that Minister increases his real authority $E_{M}$ so that he cares more for upper-level projects, if his benefit from this type of projects $b_{N}$ is higher, the level of political control $E_{P}$ is lower, the benefit from bottom-level projects $B_{n}$ is lower, the effort of Agent $e_{A}$ is higher, and the congruent parameter $\alpha_{n}$ is higher.

We assume that the two systems of equations (5) and (7) have unique stable intersections $\left(E_{P}^{h}, E_{M}^{h}, e_{M}^{h}, e_{A}^{h}\right)$ and $\left(E_{P}^{l}, E_{M}^{l}, e_{M}^{l}, e_{A}^{l}\right)$. Then, the properties of the cost function $c(\cdot), c(0)=0$, $c^{\prime}(0)=0, c^{\prime}(1)=\infty, c^{\prime}(\cdot) \geq 0, c^{\prime \prime}(\cdot)>0$, allow to formulate the first proposition. 
Proposition 1 The higher the level of rents and the lower the Politician's effort on screening policy projects, the higher the Minister's initiative on project $N$ and the lower his initiative on project $n$.

Proof of Proposition 1. See Appendix.

Comparing the unique solutions of systems (5) and (7) we obtain that the difference between Minister's efforts for screening projects $N$ and $n$ is greater under low accountability than under high accountability. Thus, in a low accountability regime Minister cares more for projects over which he has real authority $(N)$ and is more tempted to rubber-stamp the projects over which he has formal authority $(n)$. In particular, if Politician pursues only rent-seeking, this increases the Minister's initiative on project $N$, resulting in crowding out his effort to acquire information about lower-level projects $(n)$.

Extending this result we find that for any middle link within the hierarchy (in our case Minister) the increase of the higher-level actor's efforts reduces the lower-level actor's initiative. This result is based on Aghion and Tirole's conclusion that the agent demonstrates more initiative when the principal's interference becomes lower. The downward sloping of the agent's reaction curve contrary to the upward sloping of the standard monitoring model is crucial for this result ${ }^{8}$.

Within the multilevel government hierarchy, if the highest-level actor places greater discretion on the next-level actor (Politician who extracts rents fully), she gives him (Minister) real authority over decisions, and thus reinforces his initiative. Then, the next-level actor increases efforts for projects, over which he has real authority, and decreases efforts for projects, over which he has formal authority. This produces the same incentive trade-off for the next-level actor and so on. Thus, the lower the level of accountability, the more real authority is expanded downward along the hierarchy.

Taking into account the reaction curves, we can define the level of equilibrium rents as $\rho^{*}$. As mentioned previously, Politician has two alternatives: to please voters in order to be reelected or to extract all income as rents in the first period and forget about reelection, i.e., to follow the Leviathan-like policy. However, under our assumptions Politician benefits from government activity and has a private gain of $B_{N}$, so that in some way she always cares for implementing policy projects. Under low accountability following the Leviathan-like policy Politician extracts rent that equals (6). We focus on the subgame-perfect Nash equilibrium in which the voters hold Politician accountable, or the voters maximize their utility, anticipating that the incumbent will then choose the amount of rent to be reelected.

Proposition 2 In the high accountability regime Politician extracts rent at the level $\rho^{*}=$

\footnotetext{
${ }^{8}$ For details see Aghion and Tirole (1997), pp. 10-11.
} 
$\left.\max \left[0, y-R-\left(Q^{h}-Q^{l}\right)-c_{P}\left(E_{P}^{h}\right)\right)\right]$ where

$Q^{j}=E_{P}^{j} B_{N}+\left(1-E_{P}^{j}\right) E_{M}^{j} \alpha_{N} B_{N}-c_{P}\left(E_{P}^{j}\right), j=h, l$.

Proof. Politician chooses to satisfy the voters if her utility under high accountability is no less than the utility under low accountability $E\left[V^{P}\right]_{\text {high }} \geq E\left[V^{P}\right]_{l o w}$ :

$$
\begin{gathered}
\bar{\rho}+R+E_{P}^{h} B_{N}+\left(1-E_{P}^{h}\right) E_{M}^{h} \alpha_{N} B_{N} \geq y-c_{P}\left(E_{P}^{l}\right)+E_{P}^{l} B_{N}+\left(1-E_{P}^{l}\right) E_{M}^{l} \alpha_{N} B_{N}, \\
\bar{\rho} \geq y-R+Q^{l}-Q^{h}-c_{P}\left(E_{P}^{h}\right) .
\end{gathered}
$$

where $Q^{j}$ is the Politician's gain from government project $N$ in either regime; $Q^{j}=E_{P}^{j} B_{N}+$ $\left(1-E_{P}^{j}\right) E_{M}^{j} \alpha_{N} B_{N}-c_{P}\left(E_{P}^{j}\right), j=h, l$.

It will be optimal for voters to announce the maximum possible level of reservation utility that leaves the incumbent with minimum rent to be reelected. Hence, in the equilibrium (8) is binding.

From (4) we know that $\bar{\rho}=y-c_{P}\left(E_{P}^{h}\right)-\bar{w}+H(\cdot)$ so that given the politician's strategy, the voters' best choice is to set the following reservation utility:

$$
\bar{w}=R+H(\cdot)+Q^{h}-Q^{l}
$$

to induce Politician to choose:

$$
\bar{\rho}=\rho^{*}=\max \left[0, y-R-\left(Q^{h}-Q^{l}\right)-c_{P}\left(E_{P}^{h}\right)\right] .
$$

The rents are extracted to a lower extent, if income $y$ is lower and value from holding office $R$ is higher. We also see that when the level of rents is higher, the level of the Minister's effort is also higher because in this case Politician gets a share of her private benefit $\alpha_{N} B_{N}$

We should control for the situation that under high accountability the amount of extracted rent makes possible the optimal government project choice. In our model it will be always the case.

Proposition 3 In the equilibrium giving up $\rho^{*}$ leaves enough revenue for the optimal policy choice.

Proof of Proposition 3. See Appendix.

\subsection{Overload by formal authority under high and low accountability}

Regulation in large organizations is too bureaucratized and the bosses are responsible for too many units. This leads to deterioration of regulation strategies and loss of control (Aghion and Tirole 1997, p. 19). Furthermore, it has been recognized that this problem is more crucial for 
government agencies compared to private organizations because government agencies function in the specific environment of the soft budget constraint and the absence of the market's pressure. Governments have a multiprincipal and multitasking nature (Tirole, 1994; Besley and Ghatak, 2003; Dixit, 2002; Burgess and Ratto, 2003). In this subsection we consider the potential for bureaucratization in governments in high and low accountability regimes.

Suppose that Minister appoints $m$ identical Agents for $m$ sets of projects (see Figure 2). Each frontline Agent $i$ screens in a set of tasks of type $n_{i}$ as described earlier and learns the payoff structure with probability $e_{A_{i}}$. The Minister's disutility of efforts is $c_{M}\left(\sum_{i} e_{M_{i}}\right)$ and $e_{M_{i}}$ is his probability of learning the payoff structure of the subordinate $i$ 's activity. We assume that the Agents' tasks are independent. There is a fixed cost $f$ per frontline bureaucratic agent.

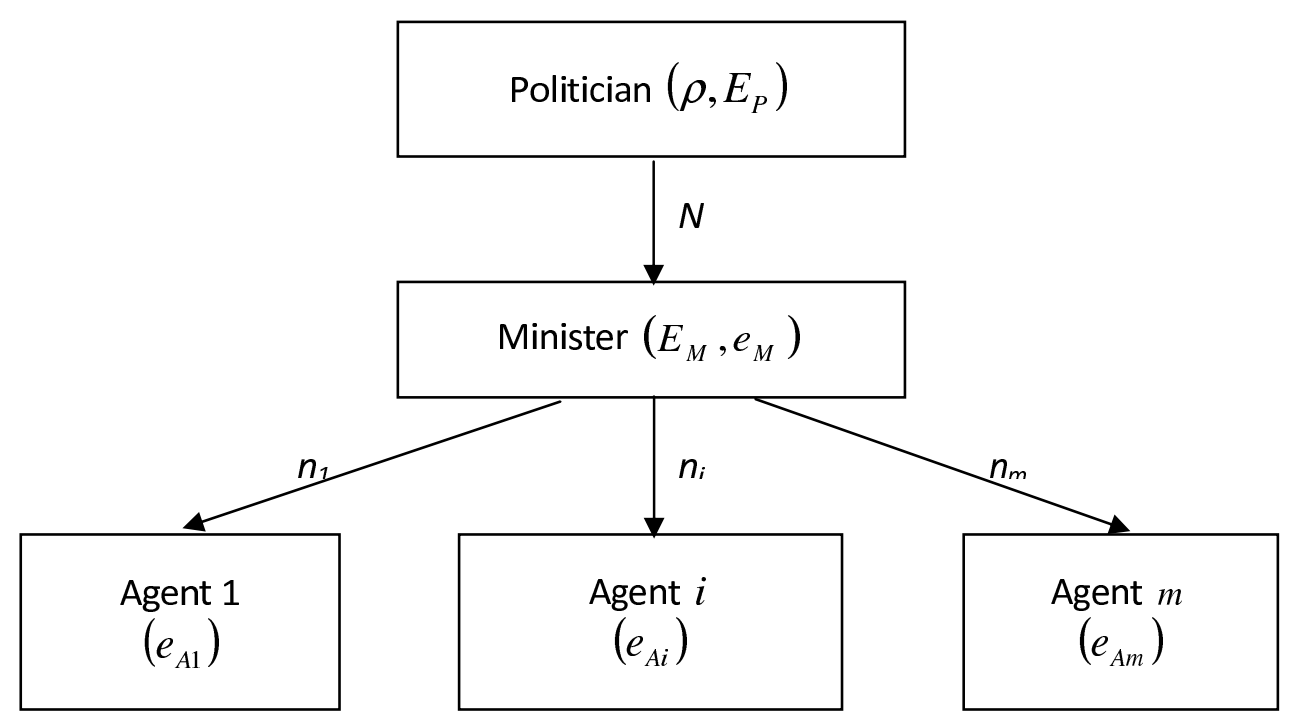

Figure 2: Flat Hierarchy

In this framework the politician's utility remains the same. Equations (1) to (3) hold, and the level of equilibrium rents (9) does not change.

The Minister's and Agents' expected utilities take the form:

$$
\begin{aligned}
& E\left[V^{M}\right]=E_{P} \beta_{N} b_{N}+\left(1-E_{P}\right) E_{M} b_{N}-c_{M}\left(E_{M}\right)+ \\
& \sum_{i}\left[e_{M_{i}} B_{n}+\left(1-e_{M_{i}}\right) e_{A_{i}} \alpha_{n} B_{n}-f\right]-c_{M}\left(\sum_{i} e_{M_{i}}\right), \\
& E\left[V^{A_{i}}\right]=e_{M_{i}} \beta_{n} b_{n}+\left(1-e_{M_{i}}\right) e_{A_{i}} b_{n}-c_{A}\left(e_{A_{i}}\right) \quad \forall i,
\end{aligned}
$$

subject to the Minister's physical constraint, $E_{M}+\sum_{i} e_{M_{i}} \leq 1$.

Each Agent's reaction curve is still given by:

$$
c_{A}^{\prime}\left(e_{A_{i}}\right)=\left(1-e_{M_{i}}\right) b_{n} \quad \forall i
$$


We assume that the equilibrium is symmetric and stable. In a manner similar to the previous section the equilibrium equations under high and low accountability can be written as:

under high accountability:

$$
\begin{gathered}
c_{P}^{\prime}\left(E_{P}\right)=\left(1-\alpha_{N} E_{M}\right) B_{N}+H^{\prime}\left(E_{P}\right), \\
c_{M}^{\prime}\left(E_{M}\right)-\frac{c_{M}^{\prime}\left(m e_{M}\right)}{m}=\left(1-E_{P}\right) b_{N}-\frac{B_{n}\left(1-\alpha_{n} e_{A}\right)}{m}, \\
c_{A}^{\prime}\left(e_{A}\right)=\left(1-e_{M}\right) b_{n} .
\end{gathered}
$$

under low accountability:

$$
\begin{gathered}
c_{P}^{\prime}\left(E_{P}\right)=\left(1-\alpha_{N} E_{M}\right) B_{N}, \\
c_{M}^{\prime}\left(E_{M}\right)-\frac{c_{M}^{\prime}\left(m e_{M}\right)}{m}=\left(1-E_{P}\right) b_{N}-\frac{B_{n}\left(1-\alpha_{n} e_{A}\right)}{m}, \\
c_{A}^{\prime}\left(e_{A}\right)=\left(1-e_{M}\right) b_{n} .
\end{gathered}
$$

Similar to the case of one Agent, using equations (10) and (11) and $E_{M}+m e_{M}=1$, we obtain:

$$
\frac{\partial E_{M}}{\partial E_{P}}<0, \quad \frac{\partial\left(m e_{M}\right)}{\partial E_{P}}>0, \quad \text { and so } \quad \frac{\partial\left(E_{M}-m e_{M}\right)}{\partial E_{P}}<0
$$

Our first result, which shows that Minister has more real authority in a low accountability government, holds as the difference between efforts of Minister for screening projects of type $N$ and $n$ is greater, the higher effort of Politician. It means that in the high accountability regime Minister cares more for projects of type $n$, over which he has formal authority, than in the low accountability regime. It follows from that under high accountability Politician discourages Minister from devoting more effort to screening projects of type $N$ by overruling his recommendations.

Proposition 4 Under high accountability it is optimal for Minister to expand formal authority rather than real authority. In both regimes Minister is in overload.

Proof. Suppose that $\left\{E_{P}^{h}(m), E_{M}^{h}(m), e_{M}^{h}(m), e_{A}^{h}(m)\right\}$ is the solution to system of equations $(10)$, and $\left\{E_{P}^{l}(m), E_{M}^{l}(m), e_{M}^{l}(m), e_{A}^{l}(m)\right\}$ is the solution to (11). Assuming for simplicity that the Politician's effort on controlling the bureaucracy is negligibly small, $E_{P}^{l}(m) \rightarrow 0$, we get that $^{9}$

\footnotetext{
${ }^{9}$ More detailed proof see in Appendix.
} 


$$
\begin{array}{r}
{\left[R_{n}\left(e_{M}^{h}(m), e_{A}^{h}(m)\right)-e_{M}^{h}(m) c_{M}^{\prime}\left(m e_{M}^{h}(m)\right)\right]} \\
+e_{M}^{h}(m)\left[-b_{N}\left(1-E_{P}^{h}(m)\right)+c_{M}^{\prime}\left(1-m e_{M}^{h}(m)\right)\right]+m \frac{\partial R_{n}}{\partial e_{A}^{h}} \frac{\partial e_{A}^{h}}{\partial m}=0 \\
{\left[R_{n}\left(e_{M}^{l}(m), e_{A}^{l}(m)\right)-e_{M}^{l}(m) c_{M}^{\prime}\left(m e_{M}^{l}(m)\right)\right]} \\
+e_{M}^{l}(m)\left[-b_{N}+c_{M}^{\prime}\left(1-m e_{M}^{l}(m)\right)\right]+m \frac{\partial R_{n}}{\partial e_{A}^{l}} \frac{\partial e_{A}^{l}}{\partial m}=0
\end{array}
$$

The expression in the first square brackets in (12) and (13) is a marginal profit from projects of type $n$ associated with a unit increase in the span of control. An extra Agent brings revenue $R_{n}$ but requires attention $e_{M}^{j}$, which increases the cost of supervision by $e_{M}^{j} c_{M}^{\prime}$. The second components of (12) and (13) indicate that hiring an extra Agent decreases the cost of effort for screening projects of type $N$ and bereaves the upper project's benefit. Aghion and Tirole call the second term in $\frac{\partial R_{n}}{\partial e_{A}^{j}} \frac{\partial e_{A}^{j}}{\partial m}>0$ by the "initiative effect" that measures the increase in the Agent's effort associated with a reduction in oversight. Note (13) differs from (12) by $E_{P}^{h} b_{N} e_{M}^{h}(m)$, which signifies the decrease of the Minister's initiative because Politician can override his decision over project $N$.

Following Aghion and Tirole we define that Minister is in overload if the marginal utility of an extra employee from projects of type $n$ (i.e., the expression in the first square brackets), with employee behavior held constant, is negative.

Equations (12) and (13) show that it is always optimal for Minister to be in overload. Equation (13) differs from (12) by $E_{P}^{h} b_{N} e_{M}^{h}(m)$. This makes evident that the marginal utility of an extra Agent is more negative in a higher accountability government.

Under high accountability Politician can override the Minister's decision and this reduces real authority of Minister and creates an incentive for him to exert more effort in his formal responsibilities. Thus, we come to the conclusion that Minister has an incentive to expand his formal authority in order to be in greater overload in the high accountability regime.

\subsection{Nested projects}

A more realistic case is when the choices of projects on different levels of the hierarchy are dependent. Suppose that the projects are nesting and the possible outcomes of project $N$ depend directly on the choice of project $n$. It is reasonable to assume that if Minister rubber-stamps project $n$ and Agent chooses its most preferred project, it leads to a different set of available projects of type $N$, which yields lower benefits for both Minister and Politician. Denote this rate of decreasing benefits by $\phi$. Then, the matrix of benefits from implementing these nesting projects for Politician, Minister and Agent can be written as in Table 2. 


\begin{tabular}{|c|c|c|}
\hline & $E_{n}$ & $1-E_{n}$ \\
\hline$E_{N}$ & $B_{N}$ & $\phi B_{N}$ \\
& $\beta_{N} b_{N}, B_{n}$ & $\phi \beta_{N} b_{N}, \alpha_{n} B_{n}$ \\
& $\beta_{n} b_{n}$ & $b_{n}$ \\
\hline $1-E_{N}$ & $\alpha_{N} B_{N}$ & $\phi \alpha_{N} B_{N}$ \\
& $b_{N}, B_{n}$ & $\phi b_{N}, \alpha_{n} B_{n}$ \\
& $\beta_{n} b_{n}$ & $b_{n}$ \\
\hline
\end{tabular}

Table 2: Payoff Structure in Case of Nested Projects

The reaction curves under high accountability take the following form:

$$
\begin{gathered}
c_{P}^{\prime}\left(E_{P}\right)=\left(1-\alpha_{N} E_{M}\right) B_{N}\left(e_{M}+\phi\left(1-e_{M}\right)\right)+H^{\prime}\left(E_{P}\right), \\
c_{M}^{\prime}\left(E_{M}\right)-c_{M}^{\prime}\left(e_{M}\right)=b_{N}\left[\left(\phi-(1-\phi)\left(E_{M}-e_{M}\right)\right)\left(1-E_{P}\right)-\right. \\
\left.E_{P} \beta_{N}(1-\phi)\right]-B_{n}\left(1-\alpha_{n} e_{A}\right), \\
c_{A}^{\prime}\left(e_{A}\right)=\left(1-e_{M}\right) b_{n} .
\end{gathered}
$$

The second equation of (14) indicates that Minister increases efforts on project $N$, over which he has real authority, relative to efforts on enlarging formal authority (projects $n$ ) if the rate of losses from his rubber-stamping of the $n$ projects $\phi$ is not very high. It is important that under the significant worsening of available $N$ projects, i.e. very small $\phi$, Minister overrides the Agent's propositions more frequently.

Furthermore, Politician makes less effort to screen projects if $\phi$ is small. It looks reasonable because if losses from Minister's rubber-stamping is very high, then Politician finds it more profitable to extract rents rather than care for government activity.

In the extreme case $\phi \rightarrow 0$, and the reaction curves of Politician and Minister under high accountability can be rewritten as:

$$
\begin{gathered}
c_{P}^{\prime}\left(E_{P}\right)=\left(1-\alpha_{N} E_{M}\right) B_{N} e_{M}+H^{\prime}\left(E_{P}\right) \\
c_{M}^{\prime}\left(E_{M}\right)-c_{M}^{\prime}\left(e_{M}\right)=\left(1-E_{P}\right) b_{N}\left(e_{M}-E_{M}\right)-\beta_{N} b_{N} E_{P}-B_{n}\left(1-\alpha_{n} e_{A}\right) .
\end{gathered}
$$

It becomes evident from (15) that Politician benefits from government project $N$ only if Minister exerts nonzero effort on project $n, e_{M}>0$. In addition, the link between projects $N$ and $n$ leads to biases in the Minister's choice behavior. By comparing (16) with (5) one can conclude that the Minister's real authority becomes significantly limited due to two effects. 
First, the scope of real authority decreases because now Minister needs to control the Agent's efforts and learn about the payoffs of candidate projects of type $n$. Otherwise, the choice of "bad" project at the lower level leads to zero gains at the top and the utility of both Politician and Minister from upper-level projects $N$ will converge to zero. This effect is described by $\left(1-E_{P}\right) b_{N}\left(e_{M}-E_{M}\right)$. We call this effect as "power" effect. The difference in Minister's efforts on projects $N$ and $n$ is critical for his gain from project $N$. Second, Minister enlarges his formal authority if Politician overrides Minister's propositions with less probability. This effect expressed by $\beta_{N} b_{N} E_{P}$ we call as "supervision" effect.

The equilibrium level of rents extracted is:

$$
\rho^{*}=\max \left[0, y-R-\left(Q^{\prime h}-Q^{\prime l}\right)-c_{P}\left(E_{P}^{h}\right)\right],
$$

where $Q^{\prime j}$ is the Politician's benefit from government projects of type $N$ in either regime and equals $Q^{\prime j}=\left(E_{P}^{j} B_{N}+\left(1-E_{P}^{j}\right) e^{j} \alpha_{N} B_{N}\right)\left(e_{M}^{j}-\phi\left(1-e_{M}^{j}\right)\right)-c_{P}\left(E_{P}^{j}\right), j=h, l$. The higher the rents, the smaller the rate of worsening of the set of available $N$ projects $(\phi)$, and the higher the probability of rubber-stamping by Minister $e_{M}$. This extension of the model is important for understanding how this changes the Politician's strategy depending on the Minister's performance.

\subsection{Monetary incentives}

The literature stresses the trade-off between control and incentives because relaxing control may increase the initiative of Agent. In a similar way, the formal and real authority framework suggests that reducing the chance to override the agent's propositions increases the agent's initiative. Another regularity is that the higher flat wage favors the Agent's effort (e.g., efficiency wage theory). Therefore, in this section we assume that the bureaucrats have a non-zero flat wage, that is they are protected by limited liability, and overview the effects of introducing monetary incentives on search intensities of all three actors. We study how the wages affect the allocation of real and formal authority in a hierarchy with nested projects. As both bureaucrats' wages are financed through the government budget, it's more reasonable to consider the case of nested projects where the Politician's utility depends on the efforts of both Minister and Agent. In this case Politician is strongly motivated to incentivize both bureaucrats to maximize her net profit from implementing government project $N$.

Suppose that Politician pays from the budget wage $w_{M} \geq 0$ to Minister and wage $w_{A} \geq 0$ to Agent. Then, the utilities of bureaucrats for projects $N$ and $n$ are $u\left(w_{M}\right)+u^{M}(N)+u^{M}(n)$ and $u\left(w_{A}\right)+u^{A}(n)$, respectively, where $u(0)=0, u^{\prime}(\cdot)>0$, and $u^{\prime \prime}(\cdot)<0$. We assume that at each level there are only two relevant projects with profits of maximum for each actor or 
zero, respectively, which implies that $\alpha_{N}=\beta_{N}$ and $\alpha_{n}=\beta_{n}$. Then, Politician pays the wages $w_{M} \geq 0$ and $w_{A} \geq 0$ if her profit is $B_{N}$, or zero if otherwise.

The politician's net profit from the approved most preferred project is $\widetilde{B}_{N}=B_{N}-w_{M}-w_{A}$. Then, the Politician's utility is $\rho+p_{I} R+u^{P}(N)-w_{M}-w_{A}$. The Minister's average gain from being informed on upper-level project $N$ is $\widetilde{b}_{N}=b_{N}+\alpha_{N} u^{M}\left(w_{M}\right)$ for $u^{M}\left(w_{M}\right)<b_{N}$ and $\widetilde{b}_{N}=\alpha_{N} b_{N}+u^{M}\left(w_{M}\right)$ for $u^{M}\left(w_{M}\right) \geq b_{N}$. In the first case, when $u^{M}\left(w_{M}\right)<b_{N}$, Minister suggests his most preferred project, so that depending on their congruence Minister receives wage $w_{M}$. The second case of $u^{M}\left(w_{M}\right) \geq b_{N}$ according to Aghion and Tirole (1997) can be called the case of "aligned incentives" because the monetary incentives are powerful enough to overcome his interest in the private benefit so that Minister always recommends the Politician's preferred project. Similarly, the Agent's average gain is $\widetilde{b}_{n}=b_{n}+\alpha_{n} u^{A}\left(w_{A}\right)$ for $u\left(w_{A}\right)<b_{n}$ and $\widetilde{b}_{n}=\alpha_{n} b_{n}+u\left(w_{A}\right)$ for $u\left(w_{A}\right) \geq b_{n}$, where as before $u(\cdot)$ is increasing and concave.

According to Aghion and Tirole (1997), in a two-tier principal-agent interaction the higher wage increases real authority for two reasons. First, it raises the agent's search intensity, so that the agent is likely to be more informed and recommends a project. Second, it reduces the principal's search intensity, so that the probability of the agent being overruled decreases, which also encourages the agent to increase his initiative. In a three-tier structure the higher wages also increase real authority but these two effects are reinforced by decreasing monitoring by Minister over lower-level projects.

Let $\left[E_{P}\left(w_{M}, w_{A}\right), E_{M}\left(w_{M}, w_{A}\right), e_{M}\left(w_{M}, w_{A}\right), e_{A}\left(w_{M}, w_{A}\right)\right]$ be a solution for the system of reaction curves of Politician and two bureaucrats in the case with monetary incentives. Then, the derivatives of the Politician's utility with respect to $w_{M}$ and $w_{A}$ are:

$$
\begin{array}{r}
\frac{d E\left[V^{P}\right]_{h i g h}}{d w_{M}}=\left(e_{M}+\left(1-e_{M}\right) \phi\right)\left[-\left(E_{P}+\alpha_{N} E_{M}\left(1-E_{P}\right)\right)+\alpha_{r} \widetilde{B}_{N}\left(1-E_{P}\right) \frac{d E_{M}}{d w_{M}}\right]+ \\
(1-\phi)\left(E_{P} \widetilde{B}_{N}+\alpha_{N} E_{M} \widetilde{B}_{N}\left(1-E_{P}\right)\right) \frac{d e_{M}}{d w_{M}} \\
\begin{aligned}
\frac{d E\left[V^{P}\right]_{h i g h}}{d w_{A}}=\left(e_{M}+\left(1-e_{M}\right) \phi\right)\left[-\left(E_{P}+\alpha_{N} E_{M}\left(1-E_{P}\right)\right)+\alpha_{N} \widetilde{B}_{N}\left(1-E_{P}\right) \frac{d E_{M}}{d w_{A}}\right]+ \\
(1-\phi)\left(E_{P} \widetilde{B}_{N}+\alpha_{N} E_{M} \widetilde{B}_{N}\left(1-E_{P}\right)\right) \frac{d e_{M}}{d w_{A}}
\end{aligned}
\end{array}
$$

The first term in the square brackets of (17) and (18) $\left(E_{P}+\alpha_{N} E_{M}\left(1-E_{P}\right)\right)$ indicates the increase in wage bill. The second term $\alpha_{N} \widetilde{B}_{N}\left(1-E_{P}\right) \frac{d E_{M}}{d w_{A}}$ corresponds to the increase in the Minister's initiative in screening projects $N$. Both these effects vary due to the relative congruence between Agent and two upper actors, Politician and Minister, $(\phi)$. If $\phi \longrightarrow 1$, Agent is allied with Politician and Minister, and so there is no additional effect of the change 
in wage bill and initiative of Minister $\left(e_{M}+\left(1-e_{M}\right) \phi \simeq 1\right)$. However, if $\phi \ll 1$, the Agent's interests are far from those of the upper actors, thus Minister more often overrules the Agent's recommendations. In this case screening by Minister of projects of type $n$ is crucial for Politician, because otherwise her profit from implementing the $N$ project is reduced dramatically. It may even lead to a decrease of wage $w_{M}$ to cut down the Minister's real authority over projects of type $N$ to spur him to be more informed about the payoffs of projects of type $n$. In this sense, the last term of $(17)$ and $\left.(18)(1-\phi)\left(E_{P}\right) \widetilde{B}_{N}+\alpha_{N} E_{M} \widetilde{B}_{N}\left(1-E_{P}\right)\right) \frac{d e_{M}}{d w_{A}}$ clearly reflects the decrease in monitoring of lower-level projects by Minister. The optimal wages when incentives are not aligned are equal to zero if $\alpha_{N}$ and $\alpha_{n}$ are small, but should be positive in general.

\section{Evidence}

We focus on two main predictions from our model. First, in low accountability countries, appointed bureaucrats have more influence, the political powers have less control over the bureaucracy, and more real authority expands downward along the government hierarchy. Second, lower political accountability is associated with smaller bureaucracy size in terms of lower government administration employment in a country. This is connected, all else equal, with the larger control of appointed bureaucrats in policy decisions so that in such countries bureaucrats climb to real power rather than expand their span of formal authority. Hence, the process of bureaucratization is likely to develop in higher political accountability regimes where appointed bureaucrats are limited in benefiting themselves from real authority. We conduct an empirical analysis of these two predictions separately, mainly because of data availability.

\subsection{Measuring political accountability}

Political accountability includes many aspects and measuring it as electoral contestability is difficult. We use several types of data to present political accountability in different perspectives. First, to allow for the multilateral nature of political accountability we use the composite index of "political accountability and voice" constructed by Kaufmann et al. (2009) that combines a number of subjective surveys to cover different dimensions closely related to political accountability. It embodies "the extent to which a country's citizens are able to participate in selecting their government, as well as freedom of expression, freedom of association, and a free media" (p. 4). This measure is normalized so that it changes from -2.5 to 2.5 , has a mean of zero, and has a standard deviation of one. The index embraces those components closest to our analysis, which indicate the level of politicians' concern with public interests, such as Democratic Accountability (Political Risk Service), Political Rights and Civil Liberties (Freedom House), and Voice to Business to express concerns about policies (World Development Research). 
Second, the different measures of corruption could be a good proxy for rents extracted by politicians. In light of this we use the data on "corruption" from Transparency International and the data on "control of corruption" from Kaufmann et al.'s dataset on indicators of governance to see whether our results using the accountability and voice index are robust. To focus on democracies we select countries with a degree of democracy no less than 4 according to Jaggers and Marshall's (2000) Polity score.

Third, political accountability in our model might refer to voter turnout. The model assumes that the level of political accountability actually depends on the reservation level of welfare and so it is determined by the citizens. By connecting the model with the real world we can suppose that the more people vote, the higher reservation level of welfare is announced and so the higher level of political accountability will be in the equilibrium. The data is extracted from the Voter Turnout Database of the International Institute for Democracy and Electoral Assistance (IDEA).

Finally, the most related measure of what we imply by political accountability in our model is term limits. Under lower accountability the politician does not care about reelection, and this refers to term-limited regimes. Therefore, we test our theory using the data on gubernatorial term limits in the United States.

\subsection{Control variables and instruments}

We allow for cross-country variation by including variables traditionally considered as controls in the literature. We use the gross national income per capita based on the purchasing power parity to take into account the fact that richer countries are characterized by higher accountability as well as bigger governments.

Testing the conjecture of larger bureaucracies in greater political accountability regimes we use the $\log$ of government administration employment and include the log of total population to control for two effects considered in the literature. Along with the direct effect of larger bureaucracies in more populous countries, the effect of economies of scale in public administration should be taken into account. As Alesina and Wacziarg (1998) and Gehlbach (2008) argue, economies of scale in supplying public goods lead to smaller governments in larger countries.

In order to control for national differences and population heterogeneity we include the data on ethnical fractionalization (Easterly and Levine, 1997; La Porta, 1999). We also use the distance from the equator to allow for colonization effects (Hall and Jones, 1999). Following Lassen (2000) we argue that ethnical fractionalization and latitude could be comparatively good instruments for political accountability which could be used to avoid the endogeneity problem due to omitted third factors and inverse causality. On the one hand, as Rauch and Evans (1999, 2000) state, ethnic diversity generates "more competition for government-created rents, leading to greater corruption and poorer bureaucratic performance generally." In particular, govern- 
ment patronage may be organized along ethnic lines, and then ethnic diversity may promote corruption. Furthermore, political interaction is more difficult in more fractionalized countries. On the other hand, Hall and Jones (1999) demonstrated that Western European colonization and influence were correlated with the distance from the equator. Finally, we take into account the number of days with precipitations during the month of the preceding elections. This instrument allows to control for the effect that bad weather spurs more people to go to vote and this increases voter turnout so according to the model the required reservation level is higher and the regime is higher accountable. At the same time there seems to be no reason why the number of days with precipitations would influence the size of government. In addition, to overcome the endogeneity problem, we use another instrument following Persson and Tabellini (2009) and Acemoglu and Yared (2010). To capture the potential level of accountability in a target country we take the incidence of democracy in neighboring countries. Specifically, we calculate a weighted average of political accountability indices using the inverse distance in kilometers between capitals as the relative weight of a target country. Accountability of politicians in neighboring countries is tightly correlated with the level of accountability in a target country, but there is no intuition to associate it with the level of government employment.

In the model of the size of government we also control for the degree of urbanization (Oates, 1985; North, 1985; Lassen, 2000; Rauch and Evans, 2000; Brown, Earle, and Gehlbach, 2007), openness of the economy (Cameron, 1978; Rodrik, 1998; Lassen, 2000; Brown, Earle and Gehlbach, 2007), and the age dependency ratio which is a percentage of people younger than 15 and older than 60 years in people aged 15 to 64 years (Lassen, 2000).

\subsection{Authority of Politicians over the Government Administration}

For measuring real authority of bureaucrats we use the variable of authority of the political powers over the administration from the "Institutional Profiles" dataset assembled by the MINEIE in 2006. The data combines the results of experts' assessments and surveys of a representative population about the institutional situation in different segments. The assessments are ordered to form ranked qualitative variables that are integers from 1 to 4 . Thus, the measure of politicians' authority over bureaucrats represents a qualitative rating that changes from $1=$ low levels of authority to $4=$ high levels of authority. For a more natural analysis, we construct the authority dummy variable that equals 1 when the initial variable is 4 , so that the politicians have high authority over administration. The other three values of low authority give the zero value of the authority dummy variable.

The analysis is conducted on the basis of the ordered probit model and instrumental variable ordered probit approach in view of the categorical nature of the dependent variable. We use accountability and voice index for 2006. Also, we include the log of the gross national income per 
capita for 2006 to take into account the effect of country richness and economic development. To control for the heterogeneity of population, the model includes a ratio of working-age persons. Table 3 contains the results using the initial authority variable of four categories. The results with the authority dummy variable is presented in Appendix. The likelihood characteristics indicate the good fitness of models.

According to the ordered probit estimation, political accountability has a coefficient of 1.135 which is significant at the $1 \%$ level and explains about $15 \%$ of change of authority of the political powers over administration. Including the log of gross national income per capita lowers the estimate to 0.62 as well as its significance to $16 \%$. However, controlling for the participation labor rate leads to an increase of the estimate and represents a more reasonable result for the large effect of accountability on the switch of authority. Thus, the estimate becomes strongly significant. These results confirm our prediction that the higher the political accountability, the higher the authority of politicians over administrations, i.e., the more they control their bureaucratic agents.

The results of the instrumental variable ordered probit estimation are also reported in Table 3. We follow the instrumental approach to avoid the endogeneity problem that might appear because of the inverse causality. A more independent bureaucracy may weaken the level of political accountability in a country by manipulating political choices and lobbying a policy better suited to its own ends. To overcome the problem of inconsistent estimates we use three instruments such as ethnic fractionalization, latitude, and weighted average of political accountability indices in neighbor countries. The results strongly support our first conclusion: the higher accountability regime is characterized by higher authority of the political powers over government administration. The marginal effects for these models unambiguously indicate that an increase in the accountability variable will decrease the probability of low authority and increase the probability of high authority of politicians over bureaucrats. Note that the income log has the same relationship sign as the political accountability index but is significant only at $20 \%$. The participation rate log has a negative significant effect because of the inverse effect explained by that the larger share of working-age people strengthens the power of the bureaucratic stakeholders.

The model estimated on the basis of the authority dummy variable yields similar results, thereby supporting our hypothesis. The coefficients before accountability are positive and strongly significant in all specifications. The effect of the accountability level on the authority of politicians is less than 1 in probit models but it is much larger in IV-probit models. All marginal effects of political accountability are highly significant except for the specifications with the $\log$ of the income, where the influence of accountability is significant at $10 \%$. The effect of the labor participation rate is negative and larger in the IV-model, while the influence of the 
income remains rather insignificant (significance at 20\%).

To ensure that our results are robust, we apply different model specifications by using the other measures of accountability regimes. Instead of the political accountability index of Kaufmann et al. we consider the control of corruption index of Kaufmann et al. and the level of corruption from Transparency International (TI). We do not present these results in detail because they are very similar to those based on the accountability and voice index. They support the suggestion that corruption is higher (i.e., accountability is lower) in countries where politicians have less control over the government administration. The control of corruption and TI corruption indices are less significant in comparison with the accountability index. Whereas in models without the income level they are significant at $0.1 \%$, in models including the log of the income per capita their significance is less. Nevertheless, these model modifications allow us to confirm the positive association between political control of bureaucrats and accountability level.

\subsection{Government administration employment: cross-country evidence}

For measuring government administration employment and wages we use data from SchiavoCampo, de Tommaso, and Mukherjee (1997) on government labor and wages. They extract these data through statistical yearbooks, yearly budget documents, personnel ministries or agencies, and inquiries to embassy personnel. Government administration "includes executive and legislative administration by departments directly dependent on the Head of State or the Parliament, together with all other ministries and administrative departments. Consequently, government administration in their definition is general government less teaching and health personnel" (p. 47). The armed forces are considered separately, so that the data we use concerns only the civilian government employment. We also distinguish the central government employment, which according to Schiavo-Campo et al., is a part of the government administration that includes all employees paid by the central government budget.

From those countries for which the data on government administration employment is available, we select 60 countries that have a degree of democracy no less than 4 according to Jaggers and Marshall's (2000) Polity score.

Figures 4, 5 - 7 plot different measures of political accountability against government administration employment for our sample of democratic countries. The data represent the positive association between political accountability and bureaucratization: the government administration is bigger in higher accountability countries.

We present the results on both total and central government employment. In this model of bureaucracy size the simple method of ordinary least squares (OLS) could give inconsistent estimates because of the endogeneity problem. Indeed, the causal mechanism derived from our 
model is from accountability to the size of government. However, there could be a feed-back effect when the enlarging bureaucracies increase their influence on the economy and "a demand for greater electoral control could arise" (Lassen, 2000, p. 14). It becomes more difficult for the constituency to control public officials. Moreover, the greater span of government influence could give more opportunities for bureaucrats to use administrative resources in pursuing private interests. To take into account this feed-back effect from the size of government to accountability we present the results of not only ordinary least squares but also a two-stage least squares (TSLS) estimation. Further, we present more efficient estimates obtained by using the maximum likelihood approach.

Table 4 contains our regression results of OLS and TSLS estimations for the total level of government employment. In the simple ordinary least squares case without the log of income per capita, political accountability is significant at the $1 \%$ level, and the coefficient is equal to 0.681. Political accountability explains $46 \%$ of the variation in total government employment in the model without income. Only a weak decrease of the estimate to 0.566 is observed in the model with income and government wage. It is interesting to note that the income variable is not significant and its inclusion does not substantially improve the OLS model.

The two-stage least squares (TSLS) estimation yields the significant coefficient of 0.804 . The inclusion of the log of income per capita increases the coefficient of accountability to 1.235 and does not reduce the level of its significance. The sign of the log of income is negative but it is insignificant. The coefficient of political accountability is the largest in the TSLS case with income. However, the inclusion of a full set of control variables returns the effect of accountability to the lower level of 0.837. Overall, all specifications strongly support the prediction that the higher the political accountability, the higher the level of total government employment.

We report two characteristics of TSLS estimation. First, F-test statistics of the first stage regression is normally larger than 10 if the instruments are considered not "weak." In our TSLS model without income this characteristic equals 10.01; consequently, the instruments can be counted as sufficient for the TSLS estimates to be reliable. Second, the hypothesis of "no overidentification" is usually tested for TSLS models. It should be examined for no overidentification because the number of instruments is greater than the number of endogenous variables. We list the "p-value" of this statistics to demonstrate that the null hypothesis of no overidentification cannot be rejected.

Figure 5 plots central rather than total government employment against political accountability. As in our model we consider larger government bureaucracies with the elected official at the top, it is interesting to compare the results on total government employment with those on central government employment. Table 5 presents these results for the level of central government employment. OLS and TSLS outcomes confirm the positive association between political 
accountability and central government employment; however, they show a drop in significance of estimates. Nevertheless, the qualitative results are unchanged.

The influence of control variables is expected and consistent with the literature. Our empirical results support the conclusions of Rodrik (1998) and Lassen (2000), namely that more open economies have larger governments. The log of population size is negative. Thus, we confirm the findings of Alesina nd Wacziarg's (1998) effect of economies of scale. This effect is also corroborated by the negative and strongly significant coefficient on urbanization. All model specifications reveal the effect of larger governments in countries with a smaller fraction of urban population. The demographic structure of countries is moderately significant and demonstrates the positive relationship: a greater number of older and younger people in an economy is associated with a larger government. The log of average government wages is negative and higher significant in total government employment regressions. In these models, its estimates are also greater by value.

We test our results on robustness using three approaches. First, we change the estimation procedure and yield more efficient estimates for all specifications by applying a maximum likelihood approach. The results remain unchanged and support our predictions.Second, we use the other measures of accountability regimes, as in the case of authority of the political powers over government administration. The qualitative results remain the same. This model modification just decreases the significance of accountability measures but supports the positive relationship between them and the size of government.

Second, following Lassen (2000) we attempt to take into account the ambiguous triple relationship between accountability, level of income, and size of government. In particular, because of the multicollinearity we exclude separately the log of income per capita and the accountability index from our models. Excluding income does not change the sign of all variables but strengthens the significance of the political accountability coefficient. Excluding political accountability makes the coefficient on income significant at the $1 \%$ level, although it was insignificant in specifications with political accountability.

Then, we allow for the feedback influence of the size of government on economic growth by considering the log of income per capita as an endogenous variable, instrumented in the same way as the political accountability index. In models with total government employment the political accountability index is positive and significant at the $1 \%$ and $5 \%$ levels while the coefficient on income is insignificant. In models with central government employment as a dependent variable both accountability and income are insignificant.

Thus, after the robustness analysis we corroborate that higher accountability countries have larger governments in terms of administration employment. Further, it is rather true for the size of central government, although the central government estimates are slightly significant. 


\subsection{Government administration employment and term limits: the United States evidence}

Finally, we test the model's prediction by addressing to term limits because low accountability in the model is defined as a regime where a politician is not reelected. The United States represents enough variation across states with and without term limits. We extract the data on government employment and payroll by functions from the State Government Finance Survey of the U.S. Bureau Census for 1972-2000. The data on term limits and other controls are used from List and Sturm (2006).

The model predicts that in term-limited states the level of government administration employment is lower. Real authority at every level of the hierarchy in these states is high and so the bureaucrats are not interested in expanding their administrative resources. Therefore, we focus on term limits at state level and distinguish whether a governor is a lame duck or not in a particular year, that is whether a governor is in his last period in office. As well, we concentrate on whether a state has one term limited legislature. The hierarchy effect is important in the model so we use the data on both state and local government administration employment. Further, we focus on full-time employees to clear up the effect of changes due to one term limit or a lame duck. Except total administration employment we report the results for financial administration and for unallocated employment. The latter indicates employment assigned to "Other Unallocated Government Administration", thus excluding financial administration, police, education, health, transport, judicial, social insurance and other administrations. This helps to distinguish those bureaucrats that does not belong to any specific department but reflect the scope of the general bureaucratic machine.

Table 6 presents our results of fixed effects estimations for the US government administration full-time employment across American states. The dependent variable is the logarithm of employment divided by state population. In all specifications both the lame duck governor and one term limited legislature are significantly negative so we confirm our theoretical prediction that states with the leaders in their last term tend to have less bureaucrats. The lame duck reduces the share of full-time government employment by about $1 \%$, and the largest decrease is for other unallocated government employment. The limit of one term provides a diminution of the government employment share $\log$ up to $6 \%$ for total and unallocated employment and about $3.5 \%$ for financial administration.

The effects of control variables are predictable. First, we include total payroll for an appropriate government administration function. The impact of pay is significantly positive. Then, we allow for total population and state income per capita. They both provide a significant negative coefficient supporting the economy of scale and efficiency effect that in richer and more 
populous states the share of government bureaucrats is lower. The logarithm of state income per capita is positive unless we include the payroll because the latter outweighs the direct state income effect. Further, we take into account the number of aged people over 65 years old and young population between 5 and 17 years old. Finally, we control for the share of republicans in the upper and lower chambers of state legislatures to capture the effect of state conservatism associated with more state employees. This effect is clearly evident for the ratio of republicans in the House of Representative, which is positively significant for total administration.

\section{Conclusion}

We highlight political agency problems and study real authority allocation within the government hierarchy given a certain level of political accountability. We argue that in low accountability countries bureaucrats have more real authority over policy decisions being formally made by politicians, as the latter care more for reelection and rents and not for meeting true public needs. Since in low accountability countries elected politicians are more engaged in rent seeking, they are more likely to rubber-stamp the decisions and proposals of their bureaucratic subordinates. This increases their initiative and discretion. As a result, at the next level of the hierarchy the bureaucrats would devote more time and effort to upper projects over which they have real authority rather than to those over which they have formal authority. This effect is passed from level to level within government bureaucracy so that real authority is expanded downward along the hierarchy. Second, our paper demonstrates that in countries with higher accountability the bureaucratic machinery is likely to enlarge because it is optimal for the higher-level bureaucrat to be in greater overload. The politician's ability to overrule the bureaucrat's proposal under higher accountability decreases his initiative, and the bureaucrat is tempted to expand his formal authority horizontally rather than vertically.

The paper drives a better understanding of existing accountability - bureaucratization regimes described in the political science literature. Our empirical results corroborate that higher government administration employment is mainly observed in high accountable countries. We extend the results of Persson and Tabellini (1999) and Lassen (2000), that less accountability leads to a more powerful bureaucracy but to a smaller government size in terms of not only spending and tax revenue but also government employment.

Discussing our empirical results, two points are worth noting. First, we confess data imperfections, and especially those concerning measuring institutions like politicians' authority over bureaucrats and political accountability and voice. There may be measurement errors and imperfect conformity, nevertheless, in the absence of any other data in this field we believe they are comparatively good proxies. Second, it should be remembered that our empirical results can be 
explained by the alternative mechanisms rather than politicians' and bureaucrats' rent-seeking behavior. First, Brousseau et al. (2010) argue that the state-as-an-organization might grow at a sustained pace as the demand addressed to the state meets the legitimacy and the resources to supply public goods. This is confirmed by the welfare state theory about the increasing demand for high living standards. Another economic reason is that higher accountable regimes redistribute more and so need bureaucrats to administer redistribution. In addition, as these regimes care about employment, they can partly solve this problem through government hiring. Third, there is a theory of de-politicized bureaucracy that stresses that the government bureaucracy is key in its capacity to contain politicians' moral hazard (Miller, 2000; Frant, 1996). Finally, reelection incentives of the politicians may promote large government bureaucracies. In particular, the politicians might aim to increase the reelection probability by enlarging the bureaucracy using patronage and vote buying activities. Alternatively, the politicians may enlarge the bureaucracy so that the latter sustains and implements their agenda in case of reelection failure.

Regarding further research it seems that the structure of government hierarchy deserves special attention; in particular, why the government bureaucracy has a more vertical structure in some countries and a more flat structure in others. More case studies on this issue might deepen our understanding about the incentives of politicians and bureaucrats in various organizational forms of government. A striking example is that of Markevich and Zhuravskaya (2009) who analyze the implications of introducing high-powered incentives for the regional leaders in Soviet Russia when a unitary-form (U-form) hierarchy was replaced by a multidivisional-form (M-form) organization.

Second, the type of political regime might be critical. Persson and Tabellini (1999) demonstrate that the size of government is lower in a presidential regime, which empirically proves to be less accountable than a parliamentary regime. However, theoretically the presidential regime is characterized by fewer rents for politicians. This is so because one of the main features of presidential regimes is the separation of decision-making power among different elected officials, which allows voters to limit the agency problem, but in practice such a formal system of checks and balances can be undermined. Nevertheless, this regime implies lower taxes and a smaller government size. Compared to presidential regimes, parliamentary regimes have less competition among the voters and are associated with larger governments. Thus, it is quite possible that the incentives of bureaucrats to expand their formal or real authority are shaped by constraints imposed by the political regime and the existing form of government in a country.

Furthermore, as Persson and Tabellini (2000) argue, political accountability should be lower in dictatorships than in democracies. It is recognized that authoritarian leaders employ repressions to remain in power and elections do not actually discipline political elites. Following our 
results, autocratic leaders should exercise more effective control the lower their accountability. Otherwise, a dictator indifferent to the public welfare may unknowingly lose his authority. This can be one explanation for why all rulers fear being overthrown (Egorov and Sonin, 2011). Second, we predict that influential but smaller government bureaucracies are more peculiar to low accountability countries. However, patronage and vote buying activities reside in authoritarian regimes, so that excessive government employment might become the way of preserving the power (e.g., Senegal, Acemoglu et al., 2011). More detail in the regard of different political regime constraints could allow us to better understand the nature of expanding governments. 


\section{References}

Acemoglu, D., D. Ticchi, and A. Vindigni (2011): "Emergence and Persistence of Inefficient States," Journal of the European Economic Association, 9(2), 177-208.

Acemoglu, D., And T. Verdier (2000): "The Choice Between Market Failures and Corruption," American Economic Review, 90(1), 194-211.

Aghion, P., And J. Tirole (1997): "Formal and Real Authority in Organizations," Journal of Political Economy, 105(1), 1-29.

Alesina, A., and G. Tabellini (2007): "Bureaucrats or Politicians? Part I: A Single Policy Task," American Economic Review, 97(1), 169-179.

(2008): "Bureaucrats or Politicians? Part II: Multiple Policy Tasks," Journal of Public Economics, 92(3-4), 426-447.

Alesina, A., And R. Wacziarg (1998): "Openness, Country Size and the Government," Journal of Public Economics, 69(3), 305-321.

Baker, G., R. Gibbons, and K. J. Murphy (1999): "Informal Authority in Organizations," Journal of Law, Economics and Organization, 15(1), 56-73.

BArro, R. J. (1973): "The Control of Politicians: An Economic Model," Public Choice, 14(1), $19-42$.

Besley, T., and M. Ghatak (2003): "Incentives, Choice, and Accountability in the Provision of Public Services," Oxford Review of Economic Policy, 19(2), 235-249.

Boadway, R., and M. Sato (2008): "Bureaucratic Advice and Political Governance," Journal of Public Economic Theory, 10(4), 503-527.

Brousseau, E., and Y. S. et Jerome Sgard (2010): "Constitutions, States and Development," Journal of Comparative Economics, forthcoming.

Brown, D. J., J. S. Earle, and S. Gehlbach (2009): "Helping Hand or Grabbing Hand? State Bureaucracy and Privatization Effectiveness," American Political Science Review, 103(2), 264-283.

Brym, R. J., And V. Gimpelson (2004): "The Size, Composition, and Dynamics of the Russian State Bureaucracy in the 1990s," Slavic Review, 63(1), 90-112.

Buchanan, J. (1986): Liberty, Market and State: Political Economy in the 1980s. New York: New York University Press. 
Burgess, S., And M. Ratto (2003): "The Role of Incentives in the Public Sector: Issues and Evidence," Oxford Review of Economic Policy, 19(2), 285-300.

Cameron, D. R. (1978): "The Expansion of the Public Economy: A Comparative Analysis," American Political Science Review, 72(4), 1243-1261.

Dixit, A. K. (2002): "Incentives and Organizations in the Public Sector: An Interpretative Review," Journal of Human Resources, 37(4), 696-727.

(2006): "Predatory States and Failing States: An Agency Perspective," Working Papers 71, Princeton University, Department of Economics, Center for Economic Policy Studies. (2010): "Democracy, Autocracy and Bureaucracy," Journal of Globalization and Development, $1(1)$.

Downs, A. (1967): Inside Bureaucracy. Boston: Little, Brown.

Easterly, W., and R. Levine (1997): “Africa's Growth Tragedy: Policies and Ethnic Divisions," Quarterly Journal of Economics, 112(4), 1203-1250.

Egorov, G., S. Guriev, and K. Sonin (2009): "Why Resource-Poor Dictators Allow Freer Media: A Theory and Evidence from Panel Data," American Political Science Review, 103(4), 645-668.

Egorov, G., And K. Sonin (2011): "Dictators and Their Viziers: Endogenizing the LoyaltyCompetence Trade-Off," Journal of European Economic Association, 9(5), 903-930.

Enikolopov, R. (2010): "Politicians, Bureaucrats and Targeted Redistribution: The Role of Career Concerns," Working Paper 148, New Economic School.

Evans, P., And J. E. Rauch (1999): "Bureaucracy and Growth: A Cross-National Analysis of the Effects of 'Weberian' State Structures on Economic Growth," American Sociological Review, 64(5), 748-765.

Ferejohn, J. (1986): "Incumbent Performance and Electoral Control," Public Choice, 50(1/3), $5-25$.

Gehlbach, S. (2008): "What is Big Bureaucracy? Reflections on Rebuilding Leviathan and Runaway State-building," Czech Sociological Review, 44(6), 1189-1197.

Gregory, P., and V. Lazarev (2003): "Commissars and Cars: A Case Study in the Political Economy of Dictatorship," Journal of Comparative Economics, 31(1), 1-19. 
Gurgur, T., And A. Shah (2005): "Localization and Corruption: Panacea or Pandora's Box?," Policy Research Working Paper Series 3486, The World Bank.

Guriev, S. (2004): "Red Tape and Corruption," Journal of Development Economics, 73(2), 489-504.

Hall, R. E., And C. I. Jones (1999): "Why Do Some Countries Produce So Much More Output Per Worker Than Others?," Quarterly Journal of Economics, 114(1), 83-116.

Johnson, C. A. (1982): MITI and the Japanese Miracle: The Growth of Industrial Policy, 1925-1975. Stanford: Stanford University Press.

Kaufmann, D., A. KraAy, and M. Mastruzzi (2009): "Governance Matters VIII: Aggregate and Individual Governance Indicators, 1996-2008," Policy Research Working Paper Series 4978, The World Bank.

Lassen, D. D. (2000): "Political Accountability and the Size of Government: Theory and Cross-Country Evidence," EPRU Working Paper Series 00-20, Economic Policy Research Unit (EPRU), University of Copenhagen.

Li, H., And W. C. Suen (2004): "Delegating Decisions to Experts," Journal of Political Economy, 112(1), S311-S335.

List, J. A., and D. M. Sturm (2006): "How Elections Matter: Theory and Evidence from Environmental Policy," Quarterly Journal of Economics, 121(4), 1249-1281.

Markevich, A., and E. V. Zhuravskaya (2011): "M-form Hierarchy with Poorly-Diversified Divisions: A Case of Khrushchev's Reform in Soviet Russia," Journal of Public Economics, 95, 1550-1560.

Mauro, P. (1995): "Corruption and Growth," Quarterly Journal of Economics, 110(3), 681712.

Niskanen, W. A. (1971): Bureaucracy and Representative Government. New York: AldineAtherton.

North, D. C. (1985): "The Growth of Ggovernment in the United States: An Economic Historian's Perspective," Journal of Public Economics, 28(3), 383-399.

OAtes, W. E. (1985): "Searching for Leviathan: An Empirical Study," American Economic Review, 75(4), 748-57.

Persson, T., G. Roland, and G. Tabellini (1997): "Separation of Powers and Political Accountability," Quarterly Journal of Economics, 112(4), 1163-1202. 
Persson, T., and G. Tabellini (1999): "The Size and Scope of Government: Comparative Politics with Rational Politicians," European Economic Review, 43(4-6), 699-735. (2000): Political Economics: Explaining Economic Policy. Cambridge: The MIT Press.

Porta, R. L., F. L. De Silanes, A. Shleifer, and R. Vishny (1999): "The Quality of Government," Journal of Law, Economics and Organization, 15(1), 222-279.

Rauch, J. E., And P. Evans (2000): "Bureaucratic Structure and Bureaucratic Performance in Less Developed Countries," Journal of Public Economics, 75(1), 49-71.

RodrIK, D. (1998): "Why Do More Open Economies Have Bigger Governments?," Journal of Political Economy, 106(5), 997-1032.

Schiavo-Campo, S., G. De Tommaso, and A. Mukherjee (1997): "An International Statistical Survey of Government Employment and Wages," Policy Research Working Paper Series 1806, The World Bank.

Suleiman, E. N. (1974): Politics, Power and Bureaucracy in France: The Administrative Elite. Princeton, N.J.: Princeton University Press.

(ed.) (1984): Bureaucrats and Policy Making: A Comparative Overview. New York: Holmes and Meier.

Tirole, J. (1994): "The Internal Organization of Government," Oxford Economic Papers, $46(1), 1-29$.

Treisman, D. (2002): "Decentralization and the Quality of Government," Discussion paper, Department of Political Science, University of California, Los Angeles.

- (2008): "Decentralization Dataset," Discussion paper, Department of Political Science, University of California, Los Angeles.

Tullock, G. (1965): The Politics of Bureaucracy. Washington, D.C.: Public Affairs Press.

Weber, M. (1968): Economy and Society: An Outline of Interpretive Sociology. New York: Bedminster Press. 


\section{Figures and Tables}

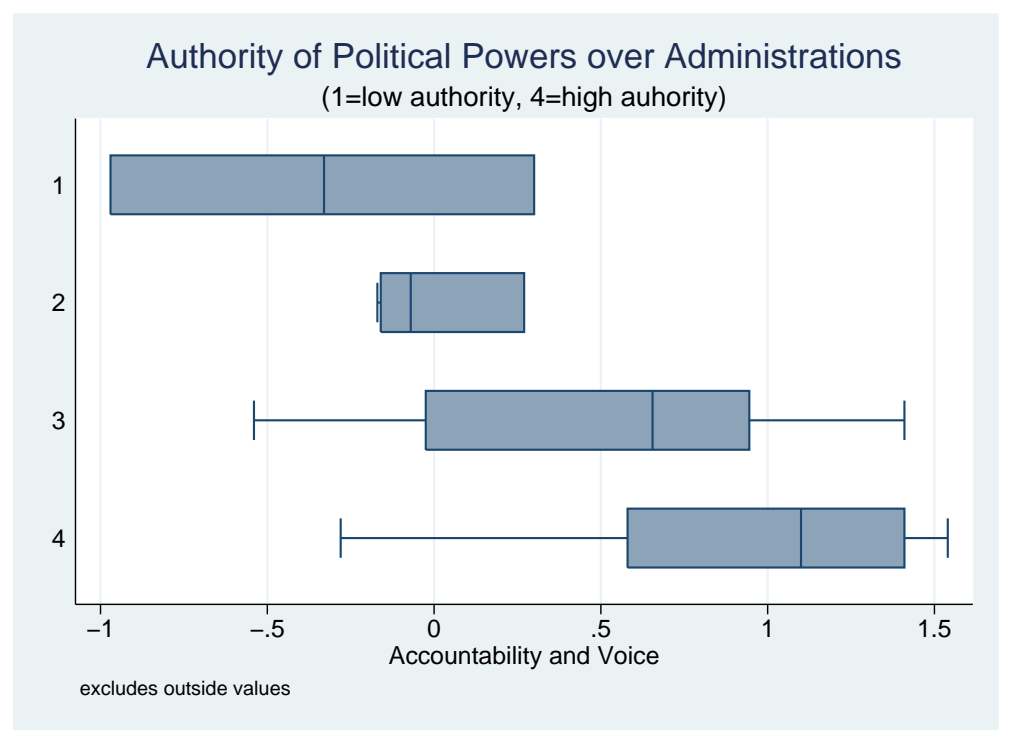

Figure 3: Authority of Political Powers over Government Administrations versus Voice and Accountability Index 


\begin{tabular}{|c|c|c|c|c|c|c|}
\hline & \multicolumn{6}{|c|}{ a5102-Authority of politicians over administration } \\
\hline & \multicolumn{3}{|c|}{ Ordered probit } & \multicolumn{3}{|c|}{ IV ordered probit } \\
\hline & $(1)$ & $(2)$ & $(3)$ & $(4)$ & $(5)$ & (6) \\
\hline \multirow[t]{2}{*}{ Political Account } & $1.135^{* * *}$ & 0.620 & $1.121^{* * *}$ & $1.306^{* * *}$ & $1.040^{* * *}$ & $1.642^{* * *}$ \\
\hline & $(0.304)$ & $(0.448)$ & $(0.424)$ & $(0.309)$ & $(0.415)$ & $(0.489)$ \\
\hline \multirow[t]{2}{*}{ Log GNI per capita } & & $0.473^{* *}$ & 0.308 & & 0.298 & 0.0687 \\
\hline & & $(0.215)$ & $(0.203)$ & & $(0.230)$ & $(0.268)$ \\
\hline \multirow[t]{3}{*}{ Log participation rate } & & & $-4.398 * * *$ & & & $-5.050 * * *$ \\
\hline & & & $(1.698)$ & & & $(1.672)$ \\
\hline & \multicolumn{6}{|c|}{ First stage for Political Accountability } \\
\hline \multirow[t]{2}{*}{ Ethnic } & & & & 0.190 & $0.475^{* *}$ & $0.466^{* *}$ \\
\hline & & & & $(0.225)$ & $(0.196)$ & $(0.201)$ \\
\hline \multirow[t]{2}{*}{ Latitude } & & & & $2.709^{* * *}$ & $2.018^{* * *}$ & $1.572^{* * *}$ \\
\hline & & & & $(0.433)$ & $(0.410)$ & $(0.458)$ \\
\hline \multirow[t]{2}{*}{ Average of neighbor PA } & & & & $0.135 *$ & 0.0811 & 0.119 \\
\hline & & & & $(0.0807)$ & $(0.0686)$ & $(0.0749)$ \\
\hline \multirow[t]{2}{*}{ Log GNI per capita } & & & & & $0.219 * * *$ & $0.253^{* * *}$ \\
\hline & & & & & $(0.0525)$ & $(0.0629)$ \\
\hline \multirow[t]{2}{*}{ Log participation rate } & & & & & & $0.934^{* *}$ \\
\hline & & & & & & $(0.444)$ \\
\hline \multirow[t]{2}{*}{ Constant } & & & & $-0.402^{* *}$ & $-2.267 * * *$ & $-5.986^{* * *}$ \\
\hline & & & & $(0.187)$ & $(0.466)$ & $(1.945)$ \\
\hline Observations & 50 & 49 & 47 & 50 & 49 & 47 \\
\hline Wald $\mathrm{chi}^{2}$ & 13.94 & 20.23 & 22.69 & 17.86 & 23.9 & 29.78 \\
\hline Log pseudolikelihood & -49.29 & -45.78 & -40.53 & & & \\
\hline Pseudo $R^{2}$ & 0.1508 & 0.2011 & 0.2687 & & & \\
\hline
\end{tabular}

Table 3: Regression Results for Authority of Politicians over Administration

Robust standard errors are in parentheses. ${ }^{* * *},{ }^{* *}$, and ${ }^{*}$ denote significance at the $1 \%, 5 \%$, and $10 \%$ levels, respectively. For the IV-ordered probit and IV-probit estimation instruments are Ethnic, Latitude and Average of political accountability indices in neighbor countries. The included controls are also used as instruments. 


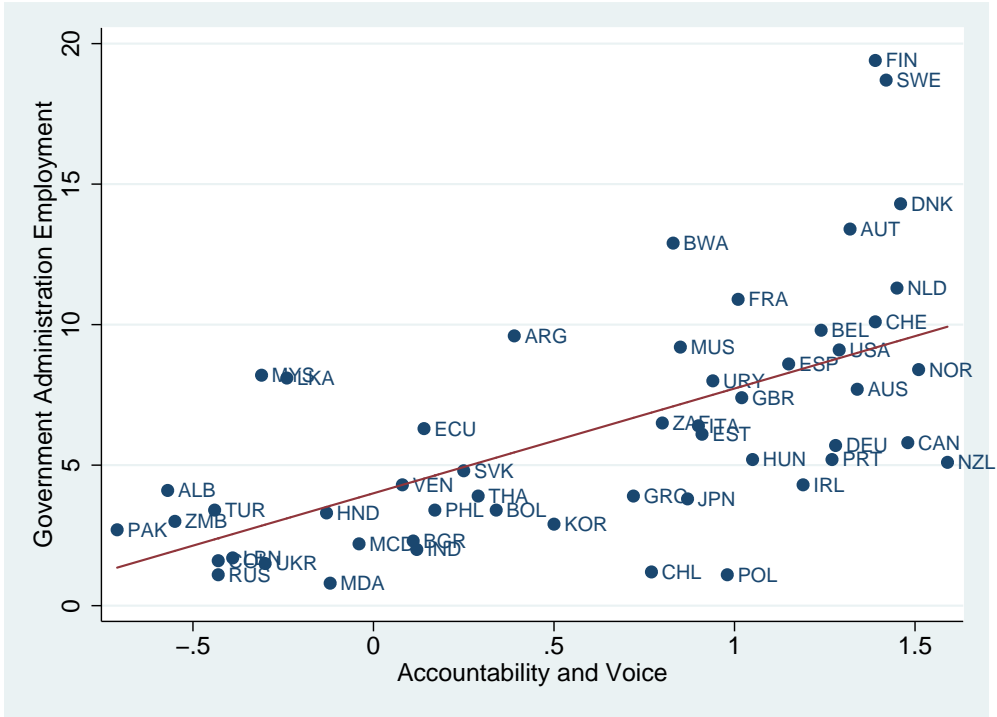

Figure 4: Government Administration Employment (to Population) versus Voice and Accountability Index

\begin{tabular}{|c|c|c|c|c|c|c|}
\hline & \multicolumn{6}{|c|}{ Log Total Government Administration Employment (to Population) } \\
\hline & $(1)$ & $(2)$ & $(3)$ & $(4)$ & $(5)$ & $(6)$ \\
\hline & ols & tsls & ols & tsls & ols & tsls \\
\hline \multirow[t]{2}{*}{ Polit Account } & $0.681^{* * *}$ & $0.804^{* * *}$ & $0.566^{* *}$ & $1.235^{* * *}$ & $0.467^{* *}$ & $0.837^{* * *}$ \\
\hline & $(0.124)$ & $(0.157)$ & $(0.294)$ & $(0.433)$ & $(0.245)$ & $(0.294)$ \\
\hline \multirow[t]{2}{*}{ Log population } & -0.0565 & -0.0461 & -0.0419 & -0.0107 & -0.0443 & -0.0153 \\
\hline & $(0.0518)$ & $(0.0496)$ & $(0.0525)$ & $(0.0722)$ & $(0.0694)$ & $(0.0762)$ \\
\hline \multirow[t]{2}{*}{ Log GNI per capita } & & & 0.0290 & -0.387 & $0.521^{* *}$ & 0.258 \\
\hline & & & $(0.183)$ & $(0.266)$ & $(0.232)$ & $(0.206)$ \\
\hline \multirow[t]{2}{*}{ Log wage } & & & -0.343 & $-0.395^{*}$ & $-0.318^{* *}$ & $-0.356^{* *}$ \\
\hline & & & $(0.209)$ & $(0.235)$ & $(0.167)$ & $(0.157)$ \\
\hline \multirow[t]{2}{*}{ Log urban popul } & & & & & $-0.914^{* * *}$ & $-0.784^{* * *}$ \\
\hline & & & & & $(0.343)$ & $(0.292)$ \\
\hline \multirow[t]{2}{*}{ Log trade } & & & & & 0.0149 & 0.0582 \\
\hline & & & & & $(0.264)$ & $(0.279)$ \\
\hline \multirow[t]{2}{*}{ Log age dependence } & & & & & $1.032^{* *}$ & $1.053^{* *}$ \\
\hline & & & & & $(0.496)$ & $(0.481)$ \\
\hline \multirow[t]{2}{*}{ Constant } & $0.986^{*}$ & 0.806 & $0.888^{*}$ & $3.918^{* *}$ & 0.803 & 1.984 \\
\hline & $(0.554)$ & $(0.541)$ & $(1.392)$ & $(1.819)$ & $(2.213)$ & $(2.397)$ \\
\hline Observations & 43 & 43 & 43 & 43 & 43 & 43 \\
\hline $\mathrm{R}^{2}$ & 0.465 & 0.451 & 0.52 & 0.398 & 0.62 & 0.585 \\
\hline $\mathrm{F}$ (first) & & 10.01 & & 43.18 & & 27.69 \\
\hline $\mathrm{P}$ (over) & & 0.33 & & 0.62 & & 0.57 \\
\hline
\end{tabular}

Table 4: Regression Results for Total Government Administration Employment (OLS and TSLS estimation) 


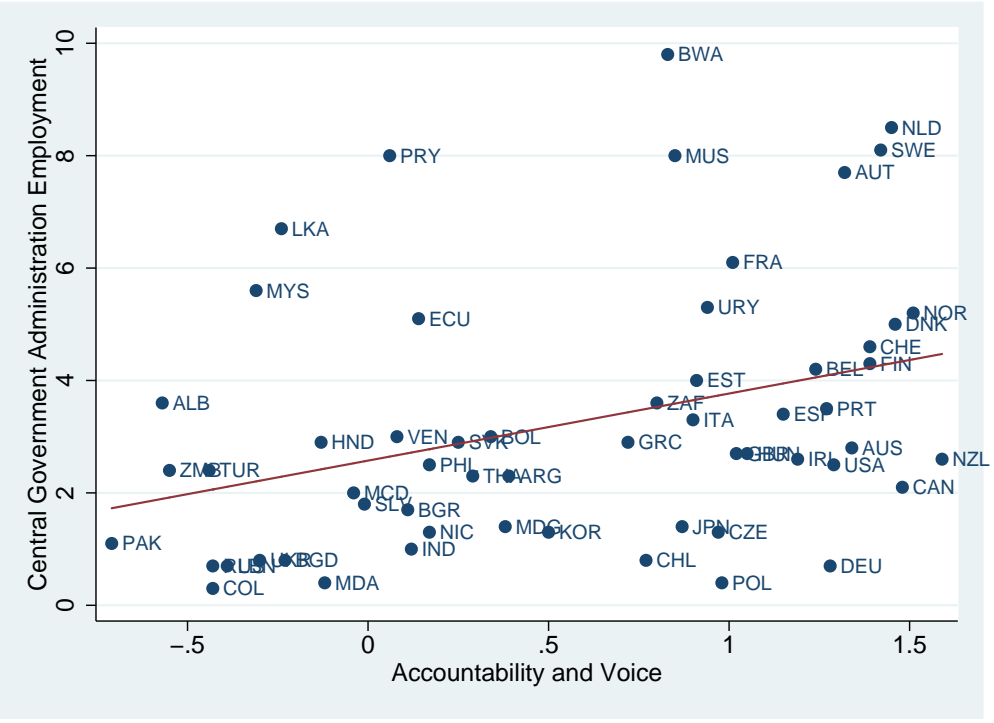

Figure 5: Central Government Administration Employment (to Population) versus Voice and Accountability Index

\begin{tabular}{|c|c|c|c|c|c|c|}
\hline & \multicolumn{6}{|c|}{ Log Central Government Admin Employment (to Population) } \\
\hline & (1) & $(2)$ & (3) & (4) & $(5)$ & (6) \\
\hline & ols & tsls & ols & tsls & ols & tsls \\
\hline \multirow[t]{2}{*}{ Polit Account } & $0.490^{* * *}$ & $0.452^{* *}$ & 0.496 & $0.869^{*}$ & 0.397 & $0.651^{\dagger}$ \\
\hline & $(0.178)$ & $(0.208)$ & $(0.399)$ & $(0.549)$ & $(0.323)$ & $(0.443)$ \\
\hline \multirow[t]{2}{*}{ Log population } & $-0.190 * * *$ & $-0.194^{* * *}$ & $-0.178 * * *$ & $-0.162^{* *}$ & $-0.143^{*}$ & -0.119 \\
\hline & $(0.0629)$ & $(0.0669)$ & $(0.0663)$ & $(0.072)$ & $(0.0848)$ & $(0.0909)$ \\
\hline \multirow[t]{2}{*}{ Log GNI per capita } & & & -0.0553 & -0.268 & $0.494^{* *}$ & 0.322 \\
\hline & & & $(0.220)$ & $(0.284)$ & $(0.211)$ & $(0.275)$ \\
\hline \multirow[t]{2}{*}{ Log wage } & & & -0.238 & -0.2704 & -0.193 & -0.221 \\
\hline & & & $(0.227)$ & $(0.223)$ & $(0.163)$ & $(0.153)$ \\
\hline \multirow[t]{2}{*}{ Log urban popul } & & & & & $-1.185^{* * *}$ & $-1.091^{* * *}$ \\
\hline & & & & & $(0.359)$ & $(0.3398)$ \\
\hline \multirow[t]{2}{*}{ Log trade } & & & & & 0.278 & 0.325 \\
\hline & & & & & $(0.233)$ & $(0.243)$ \\
\hline \multirow[t]{2}{*}{ Log age depend } & & & & & $0.978^{*}$ & $0.989^{* *}$ \\
\hline & & & & & $(0.534)$ & $(0.496)$ \\
\hline \multirow[t]{2}{*}{ Constant } & $1.719^{* *}$ & $1.777^{* *}$ & 2.256 & $3.777^{* *}$ & 1.303 & 1.893 \\
\hline & $(0.698)$ & $(0.759)$ & $(1.743)$ & $(1.958)$ & $(2.027)$ & $(2.129)$ \\
\hline Observations & 45 & 45 & 45 & 45 & 45 & 45 \\
\hline $\mathrm{R}^{2}$ & 0.339 & 0.338 & 0.356 & 0.323 & 0.527 & 0.513 \\
\hline $\mathrm{F}$ (first) & & 11.45 & & 23 & & 17.47 \\
\hline $\mathrm{P}$ (over) & & 0.081 & & 0.16 & & 0.287 \\
\hline
\end{tabular}

Table 5: Regression Results for Central Government Administration Employment (OLS and TSLS estimation) 
Robust standard errors clustered by country are in parentheses. ${ }^{* *},{ }^{* *},{ }^{*},{ }^{\dagger}$ denote significance at the 1\%,5\%,10\%,14\% levels, respectively. For the two-stage least-squares (TSLS) estimation instruments are Ethnic, Days with precipitations and Average of political accountability indices in neighbor countries. The included controls are also used as instruments. F(first) is the F-statistic with the first stage of the TSLS estimation. P-value (over) is the p-value associated with the null hypothesis of "no overidentification".

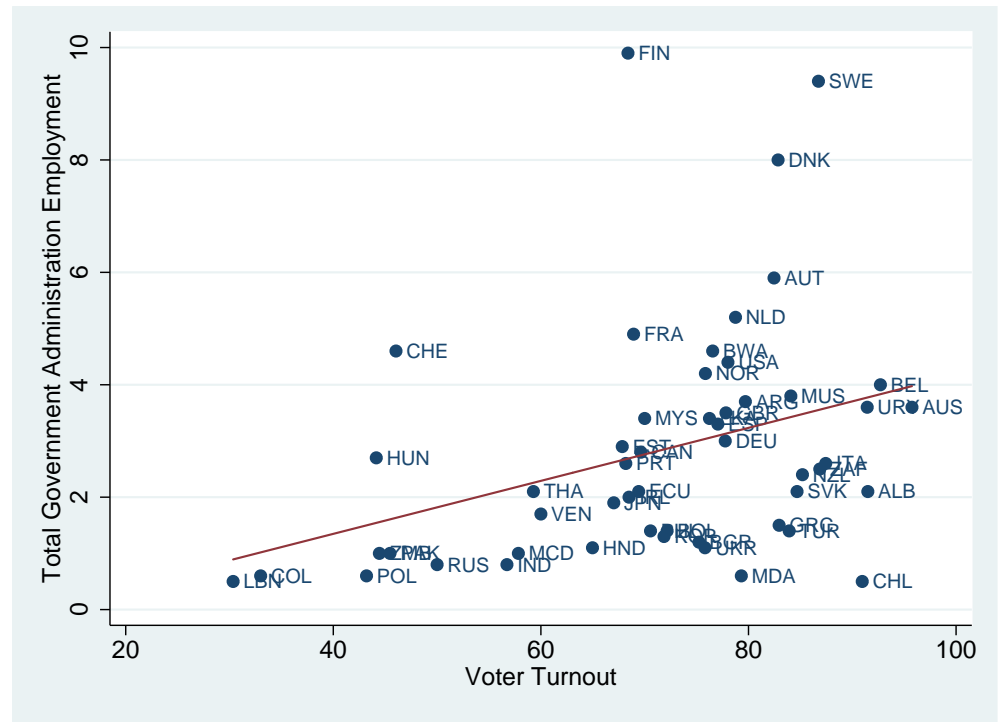

Figure 6: Total Government Administration Employment (to Population) versus Voter Turnout

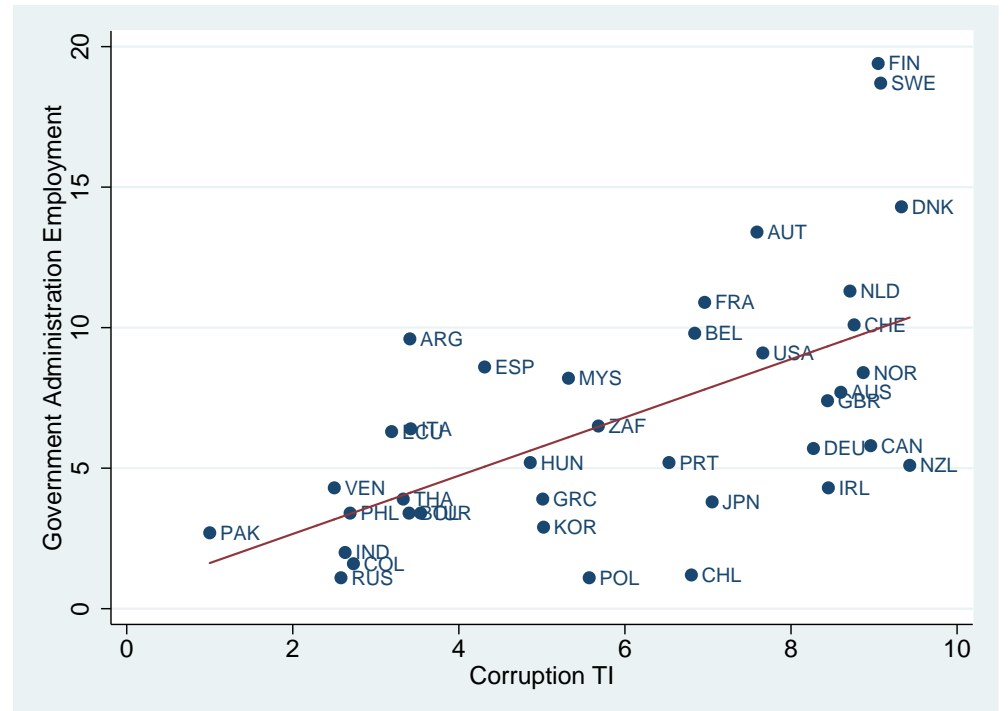

Figure 7: Total Government Administration Employment (to Population) versus Corruption TI 


\begin{tabular}{|c|c|c|c|c|c|c|}
\hline & \multicolumn{6}{|c|}{ Log US Government Administration Employment to Population } \\
\hline & (1) & $(2)$ & $(3)$ & $(4)$ & $(5)$ & $(6)$ \\
\hline & Total & Total & Financial & Financial & Unallocated & Unallocated \\
\hline \multirow[t]{2}{*}{ Lame duck } & $-0.00809^{* * *}$ & & $-0.00775^{* *}$ & & $-0.00995^{*}$ & \\
\hline & $(0.00283)$ & & $(0.00383)$ & & $(0.00593)$ & \\
\hline \multirow[t]{2}{*}{ Limit of one term } & & $-0.0563^{* * *}$ & & $-0.0358^{* * *}$ & & $-0.0538 * * *$ \\
\hline & & $(0.00719)$ & & $(0.00991)$ & & $(0.0153)$ \\
\hline \multirow[t]{2}{*}{ Log payroll } & $0.495^{* * *}$ & $0.479 * * *$ & $0.829 * * *$ & $0.827 * * *$ & $0.924^{* * *}$ & $0.924^{* * *}$ \\
\hline & $(0.0194)$ & $(0.0190)$ & $(0.0130)$ & $(0.0129)$ & $(0.0123)$ & $(0.0123)$ \\
\hline \multirow[t]{2}{*}{ Log population } & $-0.342^{* * *}$ & $-0.343^{* * *}$ & $-0.380^{* * *}$ & $-0.381 * * *$ & $-0.233^{* * *}$ & $-0.233^{* * *}$ \\
\hline & $(0.0185)$ & $(0.0180)$ & $(0.0253)$ & $(0.0252)$ & $(0.0389)$ & $(0.0387)$ \\
\hline \multirow[t]{2}{*}{ Log income per capita } & $-0.306^{* * *}$ & $-0.295^{* * *}$ & $-0.634^{* * *}$ & $-0.634^{* * *}$ & $-0.744^{* * *}$ & $-0.746^{* * *}$ \\
\hline & $(0.0182)$ & $(0.0178)$ & $(0.0151)$ & $(0.0150)$ & $(0.0158)$ & $(0.0157)$ \\
\hline \multirow[t]{2}{*}{ Rep share in the Senate } & 0.00689 & 0.00452 & $-0.0441^{* *}$ & $-0.0446^{* *}$ & -0.0250 & -0.0263 \\
\hline & $(0.0151)$ & $(0.0147)$ & $(0.0206)$ & $(0.0204)$ & $(0.0322)$ & $(0.0320)$ \\
\hline \multirow[t]{2}{*}{ Rep share in the House } & $0.0388^{* *}$ & $0.0351^{* *}$ & 0.0366 & 0.0334 & 0.0535 & 0.0489 \\
\hline & $(0.0178)$ & $(0.0173)$ & $(0.0243)$ & $(0.0241)$ & $(0.0378)$ & $(0.0375)$ \\
\hline \multirow[t]{2}{*}{ Log share of aged pop } & $-0.0960 * * *$ & $-0.108 * * *$ & $-0.0775^{* *}$ & $-0.0866^{* * *}$ & 0.0221 & 0.00963 \\
\hline & $(0.0242)$ & $(0.0236)$ & $(0.0332)$ & $(0.0332)$ & $(0.0511)$ & $(0.0509)$ \\
\hline \multirow[t]{2}{*}{ Log share of young pop } & $0.109^{* * *}$ & $0.109^{* * *}$ & -0.0351 & -0.0358 & $0.181^{* * *}$ & $0.180^{* * *}$ \\
\hline & $(0.0174)$ & $(0.0169)$ & $(0.0237)$ & $(0.0236)$ & $(0.0367)$ & $(0.0365)$ \\
\hline \multirow[t]{2}{*}{ Constant } & $-2.196^{* * *}$ & $-2.109 * * *$ & $-3.034^{* * *}$ & $-3.022^{* * *}$ & $-4.262^{* * *}$ & $-4.253^{* * *}$ \\
\hline & $(0.247)$ & $(0.240)$ & $(0.305)$ & $(0.304)$ & $(0.475)$ & $(0.472)$ \\
\hline Observations & 1,034 & 1,034 & 1,034 & 1,034 & 1,034 & 1,034 \\
\hline Number of states & 47 & 47 & 47 & 47 & 47 & 47 \\
\hline R-squared & 0.667 & 0.684 & 0.854 & 0.855 & 0.865 & 0.866 \\
\hline $\mathrm{F}$ test model & 244.6 & 264.4 & 715.1 & 722.7 & 783.6 & 792.3 \\
\hline
\end{tabular}

Table 6: Regression Results for US Government Administration Full-time Employment

Robust standard errors are in parentheses. ${ }^{* * *},{ }^{* *},{ }^{*}$ denote significance at the $1 \%, 5 \%$, and $10 \%$ levels, respectively. All specifications report fixed-effect estimates for state and local government administration employment by function: total, financial administration and unallocated administration employment. The latter indicates employment assigned to "Other Unallocated Government Administration", thus excluding financial administration, police, education, health, transport, judicial, social insurance and other administrations. The sample includes all states except Alaska, District of Columbia, Hawaii, and Nebraska. 


\section{Appendix}

\section{A Proofs}

Proposition 1. Proof. Using the first equation of (5) and the Minister's binding physical constraint $E_{M}+e_{M}=1$, we obtain:

$$
\frac{\partial E_{M}}{\partial E_{P}}<0, \quad \frac{\partial e_{M}}{\partial E_{P}}>0, \quad \text { and so } \frac{\partial\left(E_{M}-e_{M}\right)}{\partial E_{P}}<0 .
$$

Taking into account the envelope theorem and properties of function $c(\cdot), c(0)=0, c^{\prime}(0)=0$, $c^{\prime}(1)=\infty, c^{\prime}(\cdot) \geq 0, c^{\prime \prime}(\cdot)>0$, it can be shown that both systems of equations (5) and $(7)$ have the only inferior solution $\left(E_{P}^{h}, E_{M}^{h}, e_{M}^{h}, e_{A}^{h}\right)$ and $\left(E_{P}^{l}, E_{M}^{l}, e_{M}^{l}, e_{A}^{l}\right)$, where all effort levels are between 0 and 1 , and $E_{P}^{h}>E_{P}^{l}, E_{M}^{h}<E_{M}^{l}, e_{M}^{h}>e_{M}^{l}, e_{A}^{h}<e_{A}^{l}$, and so $E_{M}^{h}-e_{M}^{h}<E_{M}^{l}-e_{M}^{l}$

Proposition 3. Proof. The proposition argues that the following should hold:

$$
\rho^{*} \leq y-c_{P}\left(E_{P}^{h}\right)
$$

or

$$
y-R-\left(Q^{h}-Q^{l}\right)-c_{P}\left(E_{P}^{h}\right) \leq y-c_{P}\left(E_{P}^{h}\right),
$$

and

$$
Q^{h}-Q^{l} \geq-R
$$

It is true because $Q^{h}-Q^{l}$ is always positive. It follows from proposition 1, which states that under high accountability Politician makes her decision with more effective control, that is $E_{P}^{h}>E_{P}^{l}$.

Proposition 4. Proof. Suppose that $\left\{E_{P}^{h}(m), E_{M}^{h}(m), e_{M}^{h}(m), e_{A}^{h}(m)\right\}$ is the solution to system of equations (10), and $\left\{E_{P}^{l}(m), E_{M}^{l}(m), e_{M}^{l}(m), e_{A}^{l}(m)\right\}$ is the solution to (11). Let us assume for simplicity of the proof that in the extreme case $E_{P}^{l}(m) \rightarrow 0$. Then, the Minister's utilities under high and low accountability will be:

$$
\begin{array}{r}
E\left[V^{M}\right]_{h i g h}=E_{P}^{h}(m) \beta_{N} b_{N}+\left(1-E_{P}^{h}(m)\right) E_{M}^{h}(m) b_{N}+m R_{f}\left(e_{M}^{h}(m), e_{A}^{h}(m)\right) \\
-c_{M}\left(E_{M}^{h}(m)\right)-c_{M}\left(m e_{M}^{h}(m)\right), \\
E\left[V^{M}\right]_{l o w}=E_{M}^{l}(m) b_{N}+m R_{n}\left(e_{M}^{l}(m), e_{A}^{l}(m)\right)-c_{M}\left(E_{M}^{l}(m)\right)-c_{M}\left(m e_{M}^{l}(m)\right),
\end{array}
$$

where $R_{n}\left(e_{M}^{j}(m), e_{A}^{j}(m)\right)=e_{M}^{j}(m) B_{n}+\left[1-e_{M}^{j}(m)\right] e_{A}^{j}(m) \alpha_{n} B_{n}-f$ is the Minister's revenue per Agent. We also know that Minister is constrained in his capabilities and under full charge 
we have $E_{M}^{j}+m e_{M}^{j}=1$, where $j=h, l$ signifies a type of regime (high or low accountability). Since $E_{M}^{j}=1-m e_{M}^{j}$, it follows that:

$$
\begin{gathered}
E\left[V^{M}\right]_{h i g h}=E_{P}^{h}(m) \beta_{N} b_{N}+\left(1-E_{P}^{h}(m)\right) b_{N}\left(1-m e_{M}^{h}(m)\right) \\
+m R_{n}\left(e_{M}^{h}(m), e_{A}^{h}(m)\right)-c_{M}\left(1-m e_{M}^{h}(m)\right)-c_{M}\left(m e_{M}^{h}(m)\right), \\
E\left[V^{M}\right]_{l o w}=b_{N}\left(1-m e_{M}^{l}(m)\right)+m R_{n}\left(e_{M}^{l}(m), e_{A}^{l}(m)\right) \\
-c_{M}\left(1-m e_{M}^{l}(m)\right)-c_{M}\left(m e_{M}^{l}(m)\right) .
\end{gathered}
$$

After the envelope theorem is used and $m$ is treated as a real number, one can obtain the optimal span of control from:

$$
\begin{gathered}
\frac{d E\left[V^{M}\right]_{h i g h}}{d m}=\left(1-E_{P}^{h}(m)\right) b_{N}\left(-e_{M}^{h}(m)\right)+e_{M}^{h}(m) c_{M}^{\prime}\left(1-m e_{M}^{h}(m)\right) \\
+\left[R_{n}\left(e_{M}^{h}(m), e_{A}^{h}(m)\right)-e_{M}^{h}(m) c_{M}^{\prime}\left(m e_{M}^{h}(m)\right)\right]+m \frac{\partial R_{n}}{\partial e_{A}^{h}} \frac{\partial e_{A}^{h}}{\partial m}=0 \\
\frac{d E\left[V^{M}\right]_{l o w}}{d m}=b_{N}\left(-e_{M}^{l}(m)\right)+e_{M}^{l}(m) c_{M}^{\prime}\left(1-m e_{M}^{l}(m)\right) \\
+\left[R_{n}\left(e_{M}^{l}(m), e_{A}^{l}(m)\right)-e_{M}^{l}(m) c_{M}^{\prime}\left(m e_{M}^{l}(m)\right)\right]+m \frac{\partial R_{n}}{\partial e_{A}^{l}} \frac{\partial e_{A}^{l}}{\partial m}=0
\end{gathered}
$$

Rearranging, we get:

$$
\begin{array}{r}
{\left[R_{n}\left(e_{M}^{h}(m), e_{A}^{h}(m)\right)-e_{M}^{h}(m) c_{M}^{\prime}\left(m e_{M}^{h}(m)\right)\right]} \\
+e_{M}^{h}(m)\left[-b_{N}\left(1-E_{P}^{h}(m)\right)+c_{M}^{\prime}\left(1-m e_{M}^{h}(m)\right)\right]+m \frac{\partial R_{n}}{\partial e_{A}^{h}} \frac{\partial e_{A}^{h}}{\partial m}=0 \\
{\left[R_{n}\left(e_{M}^{l}(m), e_{A}^{l}(m)\right)-e_{M}^{l}(m) c_{M}^{\prime}\left(m e_{M}^{l}(m)\right)\right]} \\
+e_{M}^{l}(m)\left[-b_{N}+c_{M}^{\prime}\left(1-m e_{M}^{l}(m)\right)\right]+m \frac{\partial R_{n}}{\partial e_{A}^{l}} \frac{\partial e_{A}^{l}}{\partial m}=0
\end{array}
$$

\section{B Infinite-horizon setting}

Before, we considered the payoff from holding office as being exogenous. However, it can be interpreted as the continuation payoff from reelection in an infinite-horizon model. In this subsection we thus endogenize the value from holding office and examine which model parameters increase the value for Politician to be in office.

Now the voters announce the reservation utility $\overline{w_{t}}$ each period $t=1,2, \ldots$ while the incumbent chooses a level of rents $\rho_{t}$ and efforts for government activity $E_{P t}$. At the end of each 
period elections are held where the voters choose between the incumbent and challenger. The incumbent may stay in office infinitely but she is prohibited from returning after losing her position once. If in any period the challenger with identical preferences replaces the incumbent, then in the next period she becomes the incumbent. The discount factor is $\delta$.

We focus on the stationary subgame perfect Nash equilibrium with $\overline{w_{t}}=\bar{w}$ and $\rho_{t}=\rho$, $E_{P t}=E_{P}$ for $\forall t$ and where the voters vote for the incumbent if and only if she provides them with a utility no less than the reservation level $\bar{w}$.

Each period Politician faces the tradeoff between pleasing the voters and thus staying in office or extracting maximum possible rents. Politician prefers to be reelected so long as:

$$
\frac{\bar{\rho}+B_{N} E_{P}^{h}+\left(1-E_{P}^{h}\right) E_{M}^{h} \alpha_{N} B_{N}}{1-\delta} \geq y-c_{P}\left(E_{P}^{l}\right)+E_{P}^{l} B_{N}+\left(1-E_{P}^{l}\right) E_{M}^{l} \alpha_{N} B_{N} .
$$

On the left side we have the stream of the discounted benefits in case Politician decides to please voters, and on the right side we have her benefit in the case of no reelection. It yields that:

$$
\bar{\rho} \geq(1-\delta)\left(y+Q^{l}\right)-Q^{h}-c_{P}\left(E_{P}^{h}\right)
$$

Politician maximizes extracted rent, and the voters choose the maximum possible level of reservation utility, so the equilibrium rent and reservation utility will be:

$$
\begin{gathered}
\rho^{*}=\max \left[0,(1-\delta)\left(y+Q^{l}\right)-Q^{h}-g_{P}\left(E_{P}^{h}\right)\right], \\
\bar{w}=\delta y+H(\cdot)+Q^{h}-(1-\delta) Q^{l}
\end{gathered}
$$

where $Q^{j}=E_{P}^{j} B_{N}+\left(1-E_{P}^{j}\right) E_{M}^{j} \alpha_{N} B_{N}-c_{P}\left(E_{P}^{j}\right), j=h, l$. The value of holding office then equals $R=y+Q^{l}$ or $R=y+E_{P}^{l} B_{N}+\left(1-E_{P}^{l}\right) E_{M}^{l} \alpha_{N} B_{N}-c_{P}\left(E_{P}^{l}\right)$.

From reaction curve $(7)$ it is known that $E_{M}^{l}=\frac{1}{\alpha_{N}}-\frac{1}{\alpha_{N} B_{N}} c_{P}^{\prime}\left(E_{P}^{l}\right)$. Therefore, $R=y+$ $B_{N}-\left(1-E_{N}^{l}\right) c_{P}^{\prime}\left(E_{P}^{l}\right)-c_{P}\left(E_{P}^{l}\right)$.

Politician prefers to stay in office, the higher the voters' income and her overall benefit from government activity without effective control $Q^{l}$; in particular, the higher the net project gain $B_{N}$ and the lower the marginal cost of effort of screening project $N$.

A higher $R$ value implies a smaller level of equilibrium rents and is associated with a higher level of political accountability. On the basis of our earlier considerations one might assert that the higher the Politician's value from holding office, the larger the process of bureaucratization and the smaller role the bureaucrats play in policy decision-making. On the contrary, a lower value from holding office is associated with a stronger but smaller government bureaucracy. 


\section{Authority of politicians over administration}

Country coverage (50):

Argentina, Benin, Bangladesh, Bulgaria, Bolivia, Brazil, Botswana, Canada, Chile, Colombia, Czech Republic, Germany, Dominican Republic, Spain, Estonia, France, United Kingdom, Greece, Guatemala, Hong Kong, Hungary, India, Ireland, Israel, Italy, Japan, South Korea, Sri Lanka, Lithuania, Madagascar, Mexico, Mali, Mozambique, Mauritius, Malaysia, Niger, Norway, New Zealand, Philippines, Poland, Portugal, Romania, Russia, Sweden, Taiwan, Turkey, Ukraine, United States of America, Venezuela, South Africa.

\begin{tabular}{|r|ccccc|}
\hline Variable & N.Obs. & Mean & Std.Dev. & Min & Max \\
\hline Authority & 50 & 3.06 & .8429782 & 1 & 4 \\
Political Accountability & 50 & .5484 & .6490695 & -.97 & 1.54 \\
Average neighbor PA & 50 & .1548499 & .7895645 & -1.771806 & 1.434834 \\
GNI per capita & $49^{\xi}$ & 16674.29 & 13150.09 & 630 & 50070 \\
Participation rate & $47^{\psi}$ & 45.44681 & 5.504182 & 35 & 54 \\
\hline
\end{tabular}

$\xi$ Without Taiwan

${ }^{\psi}$ Without Hong Kong, Israel, Taiwan

Table C.1: Descriptive statistics

\begin{tabular}{|r|ccc|}
\hline a5102 & Freq. & Percent & Cum. \\
\hline 1 & 3 & 6.00 & 6.00 \\
2 & 7 & 14.00 & 20.00 \\
3 & 24 & 48.00 & 68.00 \\
4 & 16 & 32.00 & 100.00 \\
\hline Total & 50 & 100.00 & \\
\hline
\end{tabular}

Table C.2: Tabulate statistics of the authority variable 


\begin{tabular}{|c|c|c|c|c|c|c|}
\hline & \multicolumn{6}{|c|}{ Dummy_a5102-Authority of politicians over administration } \\
\hline & \multicolumn{3}{|c|}{ Probit } & \multicolumn{3}{|c|}{ IV probit } \\
\hline & (1) & (2) & $(3)$ & $(4)$ & $(5)$ & (6) \\
\hline \multirow[t]{2}{*}{ Political Account } & $1.101^{* * *}$ & $0.745^{*}$ & $1.468^{* * *}$ & $1.233^{* * *}$ & $1.024^{*}$ & $2.333^{* * *}$ \\
\hline & $(0.372)$ & $(0.436)$ & $(0.563)$ & $(0.397)$ & $(0.641)$ & $(0.670)$ \\
\hline \multirow[t]{2}{*}{ Log GNI per capita } & & 0.274 & 0.0249 & & 0.159 & -0.425 \\
\hline & & $(0.211)$ & $(0.274)$ & & $(0.297)$ & $(0.335)$ \\
\hline \multirow[t]{2}{*}{ Log participation rate } & & & $-4.048^{*}$ & & & $-5.125^{* *}$ \\
\hline & & & $(2.154)$ & & & $(2.092)$ \\
\hline \multirow[t]{3}{*}{ Constant } & $-1.185^{* * *}$ & $-3.518^{* *}$ & 13.67 & $-1.212^{* * *}$ & -2.559 & $21.50^{* *}$ \\
\hline & $(0.357)$ & $(1.832)$ & $(8.648)$ & $(0.361)$ & $(2.471)$ & $(9.183)$ \\
\hline & \multicolumn{6}{|c|}{ First stage for Political Accountability } \\
\hline \multirow[t]{2}{*}{ Ethnic } & & & & 0.258 & $0.528^{* * *}$ & $0.521^{* * *}$ \\
\hline & & & & $(0.184)$ & $(0.176)$ & $(0.190)$ \\
\hline \multirow[t]{2}{*}{ Latitude } & & & & $2.798^{* * *}$ & $2.173^{* * *}$ & $1.602^{* * *}$ \\
\hline & & & & $(0.363)$ & $(0.452)$ & $(0.612)$ \\
\hline \multirow[t]{2}{*}{ Average neighbor PA } & & & & 0.130 & 0.0795 & $0.131^{* *}$ \\
\hline & & & & $(0.0906)$ & $(0.0525)$ & $(0.0551)$ \\
\hline \multirow[t]{2}{*}{ Log GNI per capita } & & & & & $0.211^{* * *}$ & $0.253^{* * *}$ \\
\hline & & & & & $(0.0547)$ & $(0.0780)$ \\
\hline \multirow[t]{2}{*}{ Log participation rate } & & & & & & $0.929 *$ \\
\hline & & & & & & $(0.509)$ \\
\hline \multirow[t]{2}{*}{ Constant } & & & & $-0.453^{* * *}$ & $-2.262^{* * *}$ & $-5.992^{* * *}$ \\
\hline & & & & $(0.136)$ & $(0.453)$ & $(2.326)$ \\
\hline Observations & 50 & 49 & 47 & 45 & 44 & 42 \\
\hline Wald $\mathrm{chi}^{2}$ & 8.76 & 11.38 & 12.96 & 9.65 & 11.79 & 19.59 \\
\hline Log pseudolikelihood & -25.82 & -25.02 & -21.5 & -38.94 & -30.96 & -25.33 \\
\hline Pseudo $R^{2}$ & 0.1762 & 0.1917 & 0.2694 & & & \\
\hline
\end{tabular}

Table C.3: Regression Results for Authority of Politicians over Administration where the authority variable is a dummy variable

\begin{tabular}{rccc|ccc}
\hline \hline Pr(dummy_a5102) & 0.28041246 & 0.28204999 & 0.23180869 & -0.50853371 & -0.51326835 & -0.57135746 \\
\hline Political account & $0.371^{* * *}$ & $0.252^{*}$ & $0.448^{* * *}$ & $1.233^{* * *}$ & $1.024^{*}$ & $2.333^{* * *}$ \\
& $(0.114)$ & $(0.141)$ & $(0.171)$ & $(0.397)$ & $(0.641)$ & $(0.670)$ \\
Log GNI per capita & & 0.093 & 0.008 & & 0.159 & -0.425 \\
& & $(0.073)$ & $(0.083)$ & & $(0.297)$ & $(0.335)$ \\
Log participation rate & & $-1.234^{*}$ & & & $-5.1247^{* * *}$ \\
& & & $(0.686)$ & & & $(2.092)$ \\
\hline \hline
\end{tabular}

Table C.4: Marginal Effects for Authority of Politicians over Administration (for the case of the authority dummy variable) 


\begin{tabular}{|c|c|c|c|c|c|c|}
\hline $\operatorname{Pr}(\mathrm{a} 5102=1)$ & 0.02628702 & 0.01601076 & 0.00792185 & 0.02700828 & 0.01601229 & 0.00888441 \\
\hline $\operatorname{Pr}(\mathrm{a} 5102=2)$ & 0.12339293 & 0.11876146 & 0.11380143 & 0.12539439 & 0.12772862 & 0.12999869 \\
\hline $\operatorname{Pr}(\mathrm{a} 5102=3)$ & 0.5717457 & 0.60199476 & 0.65922724 & 0.56687009 & 0.58973186 & 0.63323847 \\
\hline $\operatorname{Pr}(\mathrm{a} 5102=4)$ & 0.27857435 & 0.26323302 & 0.21904949 & 0.28072725 & 0.26652722 & 0.22787843 \\
\hline \multicolumn{7}{|l|}{$\mathrm{a} 5102=1$} \\
\hline \multirow[t]{2}{*}{ Political account } & $-0.069^{*}$ & -0.025 & -0.024 & -0.081 & -0.042 & -0.0394 \\
\hline & $(0.041)$ & $(0.028)$ & $(0.022)$ & $(0.053)$ & $(0.039)$ & $(0.046)$ \\
\hline \multirow[t]{2}{*}{ Log GNI per capita } & & $-0.019^{*}$ & -0.007 & & -0.012 & -0.002 \\
\hline & & $(0.014)$ & $(0.007)$ & & $(0.011)$ & $(0.006)$ \\
\hline \multirow[t]{2}{*}{ Log participation rate } & & & 0.096 & & & 0.121 \\
\hline & & & $(0.089)$ & & & $(0.134)$ \\
\hline \multicolumn{7}{|l|}{$\mathrm{a} 5102=2$} \\
\hline \multirow[t]{2}{*}{ Political account } & $-0.195^{* * *}$ & $-0.109^{*}$ & $-0.202^{* *}$ & $-0.226^{* * *}$ & $-0.194^{* *}$ & $-0.324^{* *}$ \\
\hline & $(0.078)$ & $(0.080)$ & $(0.090)$ & $(0.086)$ & $(0.098)$ & $(0.141)$ \\
\hline \multirow[t]{2}{*}{ Log GNI per capita } & & $-0.084^{*}$ & $-0.056^{*}$ & & -0.056 & -0.014 \\
\hline & & $(0.048)$ & $(0.043)$ & & $(0.045)$ & $(0.052)$ \\
\hline \multirow[t]{2}{*}{ Log participation rate } & & & $0.793^{* *}$ & & & $0.996^{* *}$ \\
\hline & & & $(0.392)$ & & & $(0.452)$ \\
\hline \multicolumn{7}{|l|}{$\mathrm{a} 5102=3$} \\
\hline \multirow[t]{2}{*}{ Political account } & -0.117 & -0.068 & -0.105 & -0.132 & -0.106 & -0.133 \\
\hline & $(0.091)$ & $(0.069)$ & $(0.112)$ & $(0.104)$ & $(0.092)$ & \\
\hline \multirow[t]{2}{*}{ Log GNI per capita } & & -0.052 & -0.029 & & -0.030 & -0.006 \\
\hline & & $(0.044)$ & $(0.031)$ & & $(0.034)$ & $(0.023)$ \\
\hline \multirow[t]{2}{*}{ Log participation rate } & & & 0.410 & & & 0.408 \\
\hline & & & $(0.432)$ & & & $(0.442)$ \\
\hline \multicolumn{7}{|l|}{$\mathrm{a} 5102=4$} \\
\hline \multirow[t]{2}{*}{ Political account } & $0.381^{* * *}$ & $0.202^{*}$ & $0.331^{* * *}$ & $0.440^{* * *}$ & $0.342^{* * *}$ & $0.496^{* * *}$ \\
\hline & $(0.098)$ & $(0.144)$ & $(0.134)$ & $(0.110)$ & $(0.144)$ & $(0.167)$ \\
\hline \multirow[t]{2}{*}{ Log GNI per capita } & & $0.154^{* *}$ & $0.091^{*}$ & & $0.098 \$$ & 0.021 \\
\hline & & $(0.071)$ & $(0.059)$ & & $(0.074)$ & $(0.080)$ \\
\hline \multirow[t]{2}{*}{ Log participation rate } & & & $-1.30 * *$ & & & $-1.525^{* * *}$ \\
\hline & & & $(0.560)$ & & & $(0.527)$ \\
\hline
\end{tabular}

Table C.5: Marginal Effects for Authority of Politicians over Administration 


\section{Government administration employment}

\section{Country coverage}

For all models $N=60$ with missing some countries because of data availability:

Albania, Argentina, Australia, Austria, Bangladesh, Benin, Belgium, Bolivia, Botswana, Brazil, Bulgaria, Canada, Chile, Colombia, Czech Republic, Denmark, Ecuador, El Salvador, Estonia, Finland, France, Germany, Greece, Honduras, Hungary, India, Ireland, Italy, Japan, S Korea, Lebanon, Macedonia, Madagascar, Malaysia, Mauritius, Moldova, Netherlands, New Zealand, Nicaragua, Norway, Pakistan, Paraguay, Philippines, Poland, Portugal, Russia, S Africa, Slovak Republic, Spain, Sri Lanka, Sweden, Switzerland, Thailand, Turkey, Ukraine, UK, USA, Uruguay, Venezuela, Zambia.

\begin{tabular}{|r|ccccc|}
\hline Variable & N.Obs. & Mean & Std.Dev. & Min & Max \\
\hline Political Accountability & 60 & .5558333 & .6689919 & -.717 & 1.59 \\
Average neighbor PA & 60 & .2506633 & .7613268 & -1.56052 & 1.292721 \\
GNI per capita & 60 & 10001.83 & 8127.047 & 620 & 28630 \\
Population & 60 & 48351.75 & 123342.4 & 1115 & 913600 \\
Total gov employment & 52 & 6.232692 & 4.294763 & .8 & 19.4 \\
Central gov employment & 58 & 3.243103 & 2.324478 & .3 & 9.8 \\
Eage & 52 & 2.121869 & 1.233323 & .3313673 & 6.353171 \\
Precip_days & 52 & .2314096 & .2478943 & 0 & .831 \\
Urban population & 59 & 7.60198 & 4.069133 & .4666667 & 21.83333 \\
Trade & 60 & 62.36267 & 19.04931 & 16.56 & 96.72 \\
Age dependence & 60 & .6023548 & .1479284 & .4178303 & .9757223 \\
\hline
\end{tabular}

Table D.1: Descriptive Statistics 


\begin{tabular}{|c|c|c|c|c|c|c|}
\hline & \multicolumn{3}{|c|}{ Log Total Gov Admin Employment } & \multirow{2}{*}{$\begin{array}{c}\text { Log Central } \\
(1)\end{array}$} & Gov Admin & Employment \\
\hline & (1) & $(2)$ & (3) & & $(2)$ & $(3)$ \\
\hline \multirow[t]{2}{*}{ Polit Account } & $0.852^{* * *}$ & $0.892^{* * *}$ & $0.725^{* *}$ & $0.691 * * *$ & $0.657^{*}$ & 0.434 \\
\hline & $(0.153)$ & $(0.308)$ & $(0.282)$ & $(0.199)$ & $(0.356)$ & $(0.346)$ \\
\hline \multirow[t]{2}{*}{ Log GNI per capita } & & 0.00517 & $0.460^{* *}$ & & -0.0200 & $0.618^{* *}$ \\
\hline & & $(0.180)$ & $(0.221)$ & & $(0.195)$ & $(0.272)$ \\
\hline \multirow[t]{2}{*}{ Log population } & & -0.0445 & -0.0150 & & $-0.177^{* *}$ & -0.123 \\
\hline & & $(0.0580)$ & $(0.0672)$ & & $(0.0694)$ & $(0.0789)$ \\
\hline \multirow[t]{2}{*}{ Log wage } & & & $-0.228^{*}$ & & & -0.0364 \\
\hline & & & $(0.124)$ & & & $(0.150)$ \\
\hline \multirow[t]{2}{*}{ Log urban popul } & & & $-0.881^{* * *}$ & & & $-1.274^{* * *}$ \\
\hline & & & $(0.287)$ & & & $(0.336)$ \\
\hline \multirow[t]{2}{*}{ Log trade } & & & 0.0889 & & & 0.290 \\
\hline & & & $(0.186)$ & & & $(0.212)$ \\
\hline \multirow[t]{2}{*}{ Log age depend } & & & $1.236^{* *}$ & & & $1.223^{* *}$ \\
\hline & & & $(0.485)$ & & & $(0.577)$ \\
\hline \multirow[t]{2}{*}{ Constant } & $0.277^{* *}$ & 0.615 & 0.499 & $-0.319^{* *}$ & 1.575 & 0.304 \\
\hline & $(0.116)$ & $(1.404)$ & $(1.641)$ & $(0.146)$ & $(1.497)$ & $(1.923)$ \\
\hline \multicolumn{7}{|c|}{ First Stage for Political Accountability } \\
\hline \multirow[t]{2}{*}{ Ethnic } & -0.238 & $0.510^{* *}$ & $0.589^{* *}$ & -0.219 & $0.487^{* *}$ & $0.521^{*}$ \\
\hline & $(0.295)$ & $(0.228)$ & $(0.264)$ & $(0.309)$ & $(0.246)$ & $(0.280)$ \\
\hline \multirow[t]{2}{*}{ Days with precipitations } & $0.0305^{*}$ & 0.00516 & 0.0203 & $0.0314^{*}$ & 0.00536 & 0.0212 \\
\hline & $(0.0168)$ & $(0.0120)$ & $(0.0135)$ & $(0.0170)$ & $(0.0127)$ & $(0.0139)$ \\
\hline \multirow[t]{2}{*}{ Average neighbor PA } & $0.497 * * *$ & $0.248^{* * *}$ & $0.229^{* *}$ & $0.495^{* * *}$ & $0.244^{* * *}$ & $0.241^{* *}$ \\
\hline & $(0.0911)$ & $(0.0772)$ & $(0.0994)$ & $(0.0917)$ & $(0.0816)$ & $(0.100)$ \\
\hline \multirow[t]{2}{*}{ Log GNI per capita } & & $0.453^{* * *}$ & $0.463^{* * *}$ & & $0.449^{* * *}$ & $0.467 * * *$ \\
\hline & & $(0.0639)$ & $(0.134)$ & & $(0.0652)$ & $(0.137)$ \\
\hline \multirow[t]{2}{*}{ Log population } & & -0.0246 & $-0.109 * *$ & & -0.0246 & $-0.103^{*}$ \\
\hline & & $(0.0390)$ & $(0.0549)$ & & $(0.0400)$ & $(0.0560)$ \\
\hline \multirow[t]{2}{*}{ Log wage } & & & 0.123 & & & 0.154 \\
\hline & & & $(0.127)$ & & & $(0.129)$ \\
\hline \multirow[t]{2}{*}{ Log urban popul } & & & -0.267 & & & -0.281 \\
\hline & & & $(0.210)$ & & & $(0.212)$ \\
\hline \multirow[t]{2}{*}{ Log trade } & & & $-0.307^{*}$ & & & $-0.292^{*}$ \\
\hline & & & $(0.163)$ & & & $(0.166)$ \\
\hline \multirow[t]{2}{*}{ Log age depend } & & & $-0.805^{*}$ & & & $-0.776^{*}$ \\
\hline & & & $(0.436)$ & & & $(0.444)$ \\
\hline \multirow[t]{2}{*}{ Constant } & $0.331^{* *}$ & $-3.371^{* * *}$ & -0.965 & $0.322^{*}$ & $-3.326^{* * *}$ & -1.056 \\
\hline & $(0.167)$ & $(0.633)$ & $(1.231)$ & $(0.169)$ & $(0.642)$ & $(1.255)$ \\
\hline Log likelihood & -78.762267 & -60.126479 & -41.608847 & -100.60901 & -79.802545 & -55.256797 \\
\hline Wald $\mathrm{chi}^{2}$ & 31.06 & 43.1 & 80.2 & 12.04 & 27.44 & 64.35 \\
\hline Observations & 57 & 57 & 51 & 60 & 60 & 52 \\
\hline
\end{tabular}

Table D.2: Regression Results for Government Administration Employment

(ML estimation) 


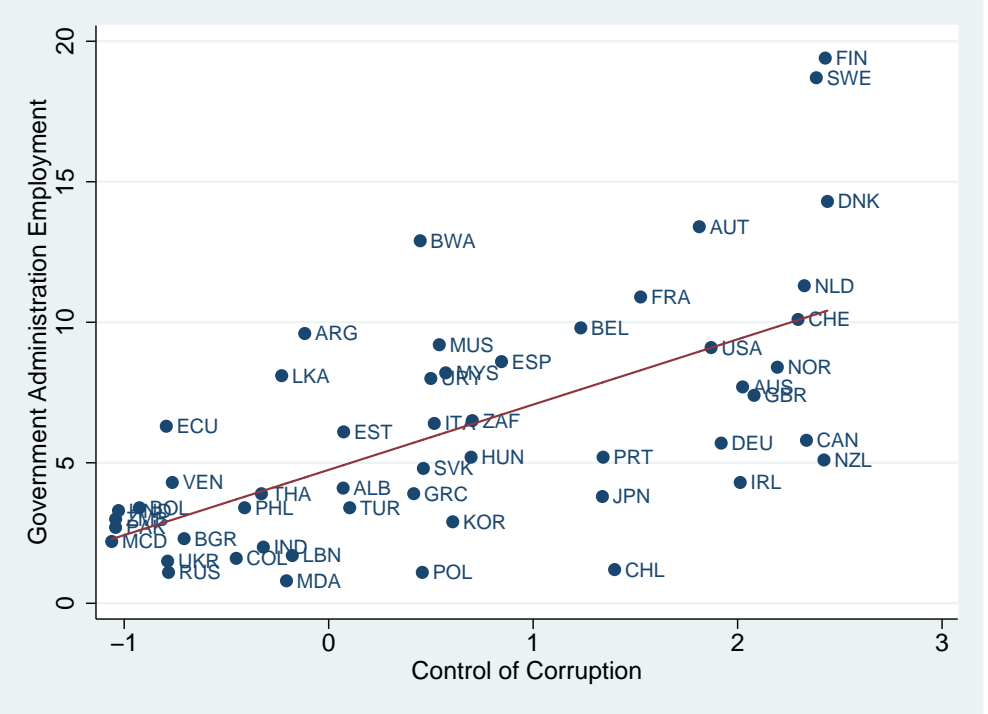

Figure D.1: Total Government Administration Employment (to Population) versus Control of Corruption

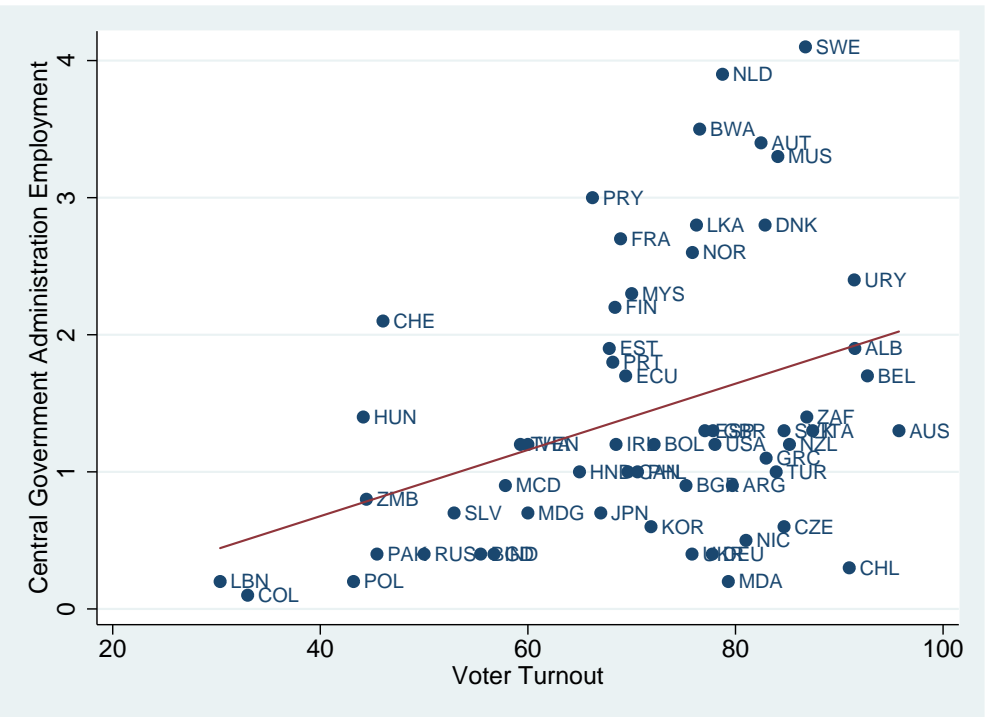

Figure D.2: Central Government Administration Employment (to Population) versus Voter Turnout 


\section{E US Other government administration employment}

\begin{tabular}{|r|ccccc|}
\hline Variable & N.Obs. & Mean & Std.Dev. & Min & Max \\
\hline Total full-time employment & 1056 & 232471.7 & 240900.9 & 19107 & 1434487 \\
Total full-time pay & 1056 & $5.22 \mathrm{E}+08$ & $7.01 \mathrm{E}+08$ & $1.26 \mathrm{E}+07$ & $5.95 \mathrm{E}+09$ \\
Financial full-time employment & 1056 & 6158.052 & 6162.285 & 623 & 41024 \\
Financial full-time pay & 1056 & $1.27 \mathrm{E}+07$ & $1.68 \mathrm{E}+07$ & 391982 & $1.56 \mathrm{E}+08$ \\
Unallocated full-time employment & 1056 & 8747.249 & 11439.32 & 557 & 79537 \\
Unallocated full-time pay & 1056 & $1.89 \mathrm{E}+07$ & $3.34 \mathrm{E}+07$ & 300190 & $3.15 \mathrm{E}+08$ \\
Lame duck & 1056 & 0.2585227 & 0.4380302 & 0 & 1 \\
One term limit & 1056 & 0.0596591 & 0.2369664 & 0 & 1 \\
Total population & 1056 & 5120895 & 5381275 & 346863 & $3.40 \mathrm{E}+07$ \\
Rep share in the Senate & 1056 & 0.4024071 & 0.1925528 & 0 & 0.8857143 \\
Rep share in the House & 1034 & 0.4164197 & 0.1802396 & 0 & 0.8428571 \\
Share of aged population & 1056 & 0.1217945 & 0.0191297 & 0.0675422 & 0.1877415 \\
Share of young population & 1056 & 0.1971208 & 0.0229456 & 0.0707399 & 0.2881041 \\
\hline
\end{tabular}

Table E.1: Descriptive Statistics 